\title{
Dynamic Testing of Gasifier Refractory
}

\author{
Final Report
}

Submitted by:

Michael D. Mann, Principal Investigator

Wayne S. Seames, Associate Professor

Devdutt Shukla, Graduate Student

Xi Hong, Graduate Student

Department of Chemical Engineering

John P. Hurley

Energy and Environmental Research Center

December, 2005

U.S. Department of Energy Grant No.: DE-FG26-01-NT41279

The University of North Dakota

P.O. Box 7101

Grand Forks, ND 58202-7101 


\section{DISCLAIMER}

This report was prepared as an account of work sponsored by an agency of the United States Government. Neither the United States Government nor any agency thereof, nor any of their employees, makes any warranty, express or implied, or assumes any legal liability or responsibility for the accuracy, completeness, or usefulness of any information, apparatus, product, or process disclosed, or represents that its use would not infringe privately owned rights. Reference herein to any specific commercial product, process, or service by trade name, trademark, manufacturer, or otherwise does not necessarily constitute or imply its endorsement, recommendation, or favoring by the United States Government or any agency thereof. The views and opinions of authors expressed herein do not necessarily state or reflect those of the United States Government or any agency thereof. 


\section{TABLE OF CONTENTS}

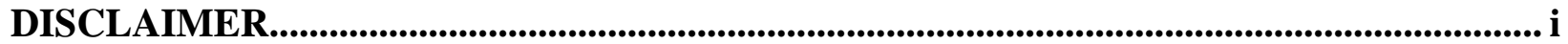

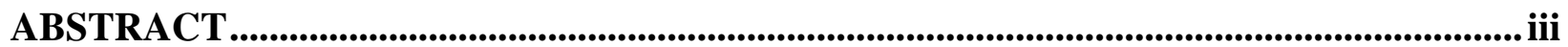

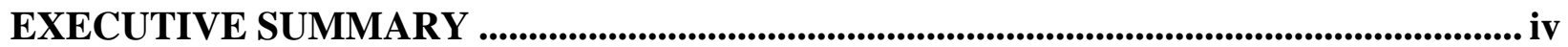

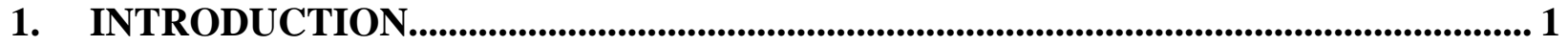

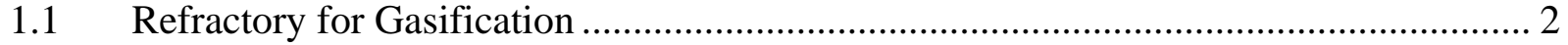

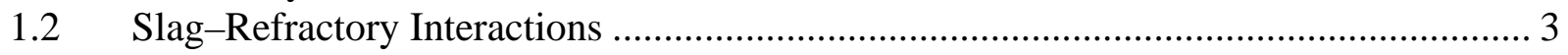

1.3 Previous Refractory Studies............................................................................ 5

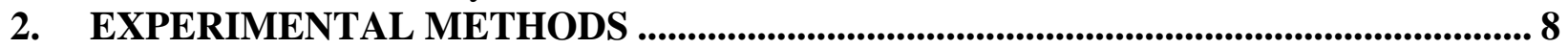

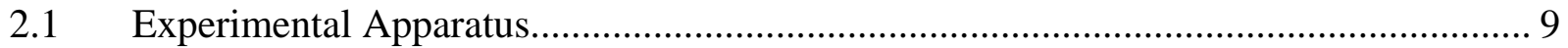

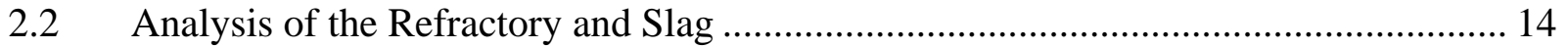

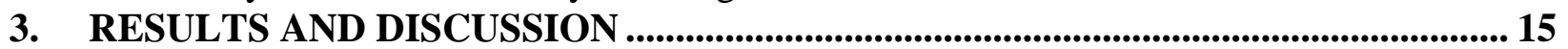

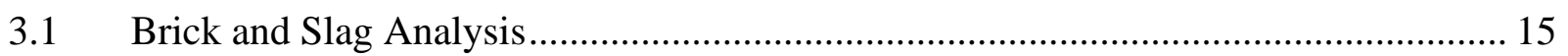

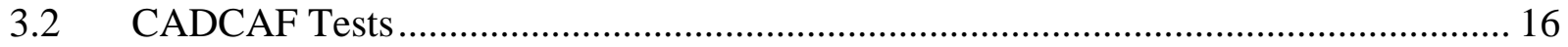

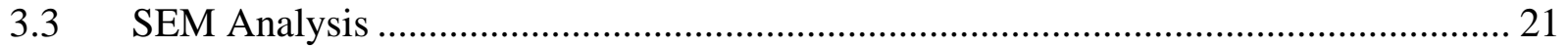

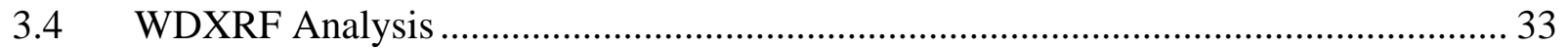

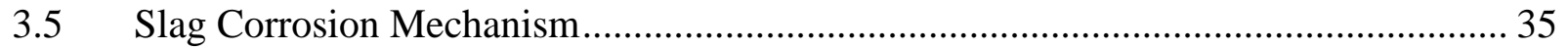

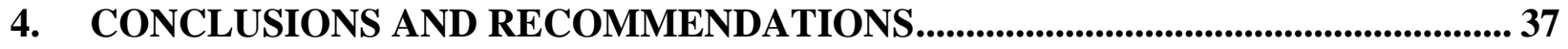

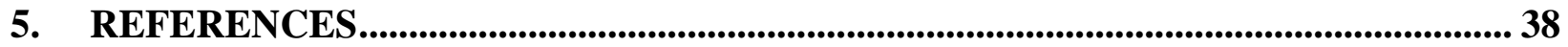




\title{
DYNAMIC TESTING OF GASIFIER REFRACTORY \\ Grant Number: DE-FG26-01-NT41279
}

\begin{abstract}
The University of North Dakota (UND) Chemical Engineering Department in conjunction with the UND Energy \& Environmental Research Center (EERC) have initiated a program to examine the combined chemical (reaction and phase change) and physical (erosion) effects experienced by refractory materials under slagging coal gasification conditions. The goal of this work is to devise a mechanism of refractory loss under these conditions.

The controlled-atmospheric dynamic corrodent application furnace (CADCAF) was utilized to simulate refractory/slag interactions under dynamic conditions that more realistically simulate the environment in a slagging coal gasifier than any of the static tests used previously by refractory manufacturers and researchers. High-alumina and high-chromia refractory bricks were tested using slags obtained from two solid fuel gasifiers. Testing was performed at $1475^{\circ} \mathrm{C}$ in a reducing atmosphere $\left(2 \% \mathrm{H}_{2}\right.$ in $\left.\mathrm{N}_{2}\right)$

The CADCAF tests show that high-chrome refractories have greater corrosion resistance than high-aluminum refractories; coal slag readily diffuses into the refractory through its grain boundaries; the refractory grains are more stable than the matrix in the tests, and the grains are the first line of defense against corrosion; calcium and alkali in the slag are more corrosive than iron; and silicon and calcium penetrate the deepest into the refractory. The results obtained from this study are preliminary and should be combined with result from other research programs. In particular, the refractory corrosion results from this study should be compared with refractories removed from commercial gasifiers.
\end{abstract}




\section{EXECUTIVE SUMMARY}

The University Of North Dakota (UND) Chemical Engineering Department in conjunction with the UND Energy \& Environmental Research Center (EERC) have initiated a program to examine the combined chemical (reaction and phase change) and physical (erosion) effects experienced by a variety of refractory materials during both normal operation and thermal cycling under slagging coal gasification conditions.

The focus of this project was to test the corrosion resistance of commercially available refractories to flowing slag and propose mechanisms of corrosion for the conditions studied. The primary objective was to carry out well-defined experiments to provide understanding and insight into the performance of refractories under a reducing atmosphere and dynamic slagging condition. Information generated from these experiments will lead to the development of the mechanisms of refractory loss under such an environment. The objective was met by simulating slag-refractory interactions using a bench-scale testing apparatus, the Controlled-Atmospheric Dynamic Corrodent Application Furnace (CADCAF), followed by analysis of the corroded refractory and slag using advanced analytical techniques.

The CADCAF was utilized to simulate refractory/slag interactions under dynamic conditions that more realistically simulate the environment in a slagging coal gasifier than any of the static tests used previously by refractory manufacturers and researchers. The CADCAF operates at temperatures up to $1650^{\circ} \mathrm{C}$ and in the presence of flowing slag. The atmosphere in the CADCAF can be controlled to simulate either reducing or oxidizing conditions. Refractory brick samples are machined to include a slag well at the top to investigate the impacts of "pools" of slag on refractory corrosion, and slag channels that are cut down the side of the brick to simulate the corrosive effects of slag running down the vertical sides of a refractory-lined vessel.

The refractories tested in this study were obtained from two commercial companies. Both highalumina and high-chromia refractories were tested. Slags used to test refractory stability were from two solid fuel gasifiers. Before the experiments, they were pulverized and sieved to -20 to +60 mesh. One of the slags is characterized by a high iron content, the second by its high calcium, sodium, and potassium content. Testing was performed at $1475^{\circ} \mathrm{C}$ in a reducing atmosphere (2\% $\mathrm{H} 2$ in $\mathrm{N} 2)$

The CADCAF tests of commercial refractories show that high-chrome refractories have greater corrosion resistance than high-aluminum refractories based upon the CADCAF tests; coal slag readily diffuses into the refractory through its grain boundaries; the refractory grains are more stable than the matrix in the tests, and the grains are the first line of defense against corrosion; calcium and alkali in the slag are more corrosive than iron; and silicon and calcium penetrate the deepest into the refractory. The results obtained from this study are preliminary and should be combined with result from other research programs. In particular, the refractory corrosion results from this study should be compared with refractories removed from commercial gasifiers. 


\section{INTRODUCTION}

Coal gasification is one of the most versatile ways to convert the energy content of coal into electricity, gaseous fuel (mainly $\mathrm{H}_{2}$ and $\mathrm{CO}$ ), and other energy forms. At the same time, it is an environmentally friendly technology that greatly reduces combustion pollutants and $\mathrm{CO}_{2}$ emissions when compared to more conventional combustion-based technologies. Because of these advantages, gasification is a key element in the U.S. Department of Energy's (DOE's) Vision 21 power program [1].

As DOE continues to advance new power systems, materials issues are often pivotal in determining the ultimate efficiency that can be reached in the system. A specific example is the need for refractories able to withstand both oxidizing and reducing environments, with high temperature strength, and the ability to resist corrosion by flowing slag and rapid thermal cycling. The University of North Dakota (UND) Chemical Engineering Department in conjunction with the UND Energy \& Environmental Research Center (EERC) has undertaken a study to thoroughly examine the combined chemical (reaction and phase change) and physical (erosion) effects experienced by a variety of refractory materials during both normal operation and thermal cycling under slagging coal gasification conditions. The goal of this work is to devise a mechanism of refractory loss under these conditions.

The work takes advantage of equipment and experimental techniques developed at the EERC under funding from several DOE programs. The controlled-atmospheric dynamic corrodent application furnace (CADCAF) was utilized to simulate refractory/slag interactions under dynamic conditions that more realistically simulate the environment in a slagging coal gasifier than any of the static tests used previously by refractory manufacturers and researchers. The CADCAF, along with advanced analytical techniques were used to evaluate the refractory 
problems facing the gasifier-based advanced power systems being developed under Vision 21.

\subsection{Refractory for Gasification}

The refractory lining is an integral part in the majority of entrained-flow gasifiers. The gasification chamber operates at temperatures between $2190^{\circ}$ and $2900^{\circ} \mathrm{F}$ and under pressures up to $6.9 \times 106 \mathrm{~Pa}$. Refractories are used to contain the severe environment and protect the gasification steel shell from erosion, corrosion, and high temperature. The main components of refractories are chromium oxides and alumina, with additives such as titania, zirconia, and magnesia and extremely low amounts of iron oxides, silica, and alkalis.

The harsh operating environment of a gasifier poses challenges for the refractory. Materials that can withstand these environments over long periods of service are necessary for a continuous, efficient, and reliable gasification process. Failure of the refractory lining may result in replacement costs as high as $\$ 1,000,000$, depending on vessel size and production down time; therefore, refractory selection and well-executed designs are pivotal to ensure the longest possible service life. Through an increase in service life, these improved materials will help to make gasification a more reliable and economic technology for fossil fuel-based power production.

A large number of refractory compositions have been evaluated historically under the gasification environment, including sintered and/or fused cast alumina-silicate, high-alumina, chromia-alumina, chrome-magnesia spinels, alumina and magnesia, alumina and chrome, and $\mathrm{SiC}$ refractory compositions [2-6]. In general, chrome oxide additions to refractory compositions were found to improve their slag resistance. For example, the studies conducted to determine the stability of Al2O3-rich refractories show that the higher the $\mathrm{Cr} 2 \mathrm{O} 3$ concentration, the lower the deterioration rate [7,8]. In addition, industrial experience also indicated that only Cr2O3-Al2O3, 
Cr2O3-Al2O3-ZrO2, and Cr2O3-MgO compositions could withstand gasifier environments long enough to be economically feasible [6,8]. According to Bakker [9,10], a minimum $75 \mathrm{wt} \%$ Cr2O3 is necessary in a refractory material for sustained material performance in slagging gasifiers.

The porosity of refractory is very important to its corrosion resistance. Slag may penetrate the refractory by capillary action. In the manufacture of gasifier refractories, the resistance is improved by using a fully dense material. However, because of the thermal gradient and differential thermal expansion encountered during the heat treatment, it is necessary to have a small amount of porosity (usually 15\% to $25 \%$ ) present in the refractory materials to reduce thermal shock.

The service life of a gasifier refractory is also dependent on many other factors, including feedstock, the temperature and pressure of operation, material throughput, and the frequency and quality of plant maintenance. Failure is usually caused by chemical corrosion or spalling. Improvements are being sought by developing new or improved refractory materials.

\subsection{Slag-Refractory Interactions}

A flowsheet listing the major types of refractory wear in a slagging gasifier is shown in Figure 1 [11]; the causes are categorized as material, refractory, and gasifier issues. In an entrained-flow gasifier, the refractory corrosion is caused by direct abrasion or through penetration of slag. The slag corrosion can occur from dissolution of refractory material into the flowing slag or by dissolution of the bond phase at the hot face, followed by freeing of refractory grains into the flowing slag. At the same time, the elevated temperature and high pressure in the gasification chamber promote the corrosion. The fact that the slag is liquid not only causes high reaction rates with refractory because of the rapid transport of slag corrodents on the refractory 


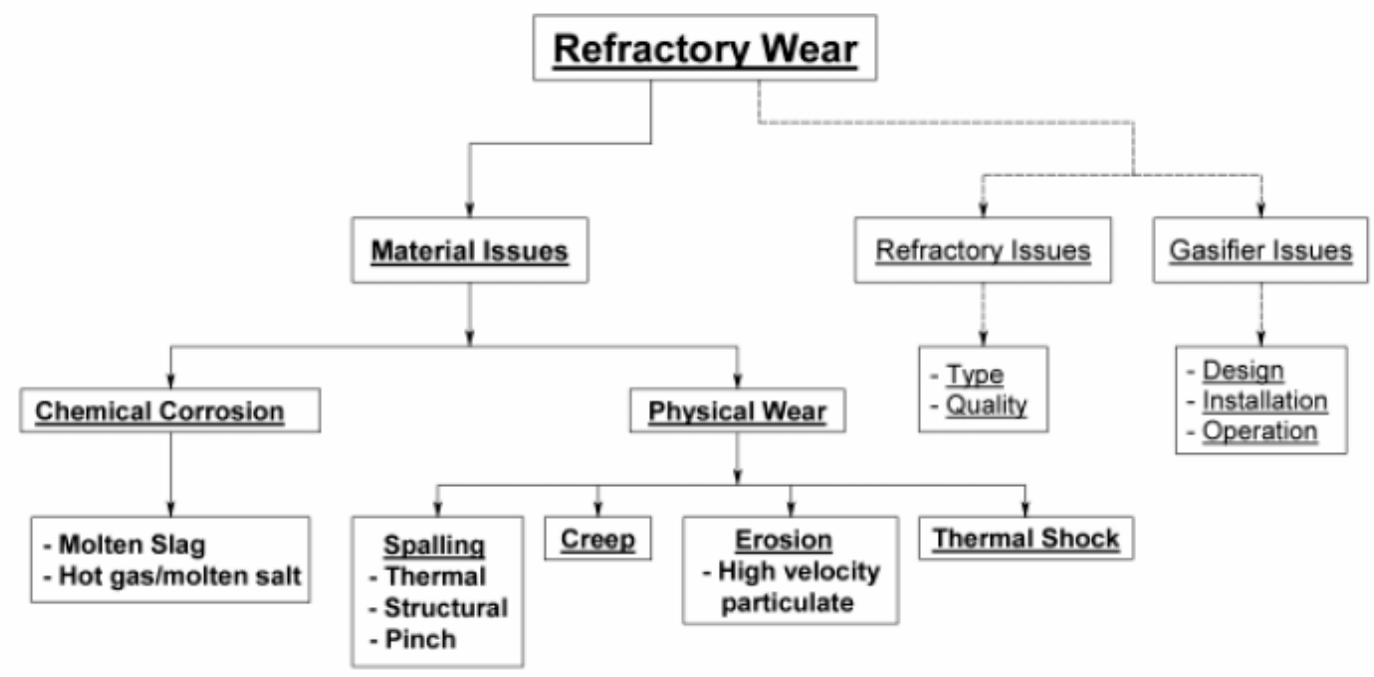

Figure 1. Causes of Refractory Wear in a Slagging Gasifier [11].

surface, but it also leads to the penetration of slag constituents into refractory. Bennett and coworkers [11] developed a relationship showing the relative depth of slag penetration into a high chrome oxide-alumina refractory for various elements as shown in Figure 2. Besides penetration, the crystallization of secondary species can also be destructive. These species may have a higher specific volume than the original material, which leads to expansion and bursting of the refractory.

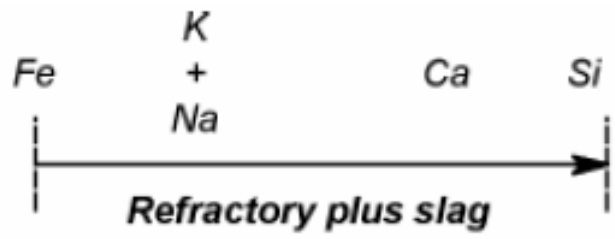

\section{Refractory Hot Face \\ Maximum Depth of Slag Penetration}

Figure 3. Relative Slag Penetration of Slag Elements into the Microstructure of a High Chrome Oxide Refractory [11].

The corrosion rate is a phenomenon that is strongly dependent on the slag composition, viscosity, solubility, and amount of slag per unit of time. For a given brick and certain process 
conditions, the corrosion rate is most dependent on slag viscosity.

\subsection{Previous Refractory Studies}

The DOE Albany Research Center has developed a degradation mechanism of highchrome refractory with coal slag. It can be described as [11]:

(1) Refractory dissolution:

$$
\mathrm{Cr}_{2} \mathrm{O}_{3} \text { (solid) } \rightarrow \mathrm{Cr}_{2} \mathrm{O}_{3} \text { (liquid) }
$$

(2) Refractory particles debonding: dissolving of particle bonds and particles infusing into slag

(3) Slag-refractory elemental replacement:

$$
\mathrm{Cr}_{2} \mathrm{O}_{3}+\mathrm{MO}_{\mathrm{x}} \rightarrow(\mathrm{M}, \mathrm{Cr})_{2} \mathrm{O}_{3} \text { (solid or liquid) }
$$

(4) Slag-refractory reaction producing new phases:

$$
\mathrm{Cr}_{2} \mathrm{O}_{3}+\mathrm{MO}_{\mathrm{x}} \rightarrow(\mathrm{M}, \mathrm{Cr})_{\mathrm{x}} \mathrm{O}_{\mathrm{y}} \text { (solid or liquid) }
$$

(5) Slag-refractory physical mismatch: variation in properties causing stress and fragmentation

(6) Slag penetration into refractory pores: slag penetrates into $14 \%-17 \%$ porosity

(7) Slag wear-abrasion-erosion: slag velocity est. 4-20 m/hour and viscosity less than 20 poise

(8) Stress (and thermal cycle) loadings resulting in fragmentation and spallation

Calcia $(\mathrm{CaO})$ and iron oxide $(\mathrm{FeO})$ were suggested to be the principal slag-reacting components in the study of oxide reaction with high-chrome sesquioxide refractory [12]. The results of that study also showed that high-chrome sesquioxides and spinel have similar interactions with respect to slag-refractory interaction. 
$\mathrm{Li}$ and coworkers studied the reaction between $\mathrm{MgO}-\mathrm{C}$ refractory, molten slag, and $\mathrm{FeC}$ alloy [13]. They found gas bubbles formed during their experiments. The bubbles mainly resulted from the reaction between $\mathrm{FeO}$ in the slag film and $\mathrm{C}$ in the refractory:

$\mathrm{FeO}+\mathrm{C} \rightarrow \mathrm{Fe}_{(\mathrm{s})}+\mathrm{CO}_{(\mathrm{g})}$

The corrosion rate was greatly influenced by the generation position and the number of bubbles generated. Bubbles generated at the refractory metal interface could enhance the local corrosion.

A study by Kim and Oh [14] showed that the corrosion of chromia refractory occurred via reaction between $\mathrm{Cr}_{2} \mathrm{O}_{3}$ of the refractory and $\mathrm{FeO}$ and $\mathrm{Al}_{2} \mathrm{O}_{3}$ in the slag. The $\mathrm{FeO}$ reacted with $\mathrm{Cr}_{2} \mathrm{O}_{3}$ at the slag-refractory interface and formed $\mathrm{FeCr}_{2} \mathrm{O}_{4}$. After all of the $\mathrm{FeO}$ was used, $\mathrm{Al}$ in the penetrating slag substituted for $\mathrm{Cr}$ in $\mathrm{Cr}_{2} \mathrm{O}_{3}$, forming $(\mathrm{Al}, \mathrm{Cr})_{2} \mathrm{O}_{3}$ at the edges of the particle, which were broken to form fragments rich in Al. The corrosion resistance of $\mathrm{Cr}_{2} \mathrm{O}_{3}$ varied with the particle size and the extent of sintering, and the higher resistance was observed in the larger and more sintered particles.

Another study of slag-refractory interactions in a reducing atmosphere [7] showed that the reaction between the chromium in the refractory and the iron in the slag can be controlled by the presence of elemental carbon in the slag; and the chromium in the $\mathrm{Cr}-\mathrm{Al}$ sesquioxide refractory and/or the Cr-Fe spinel was dissolved in the slag, resulting in loss of refractory.

Yang and Chan [15] evaluated the corrosion resistance and the microstructures of the commercial products of four $\mathrm{Cr}_{2} \mathrm{O}_{3}$-free and two $\mathrm{Cr}_{2} \mathrm{O}_{3}$-containing high-alumina refractories in a rotary slag test. The resistance of the $\mathrm{Cr}_{2} \mathrm{O}_{3}$-containing refractories to corrosion by the slag was higher than that of the $\mathrm{Cr}_{2} \mathrm{O}_{3}$-free refractories. 
Yamaguchi [16] investigated the sintering of materials in the $\mathrm{Al}_{2} \mathrm{O}_{3}-\mathrm{Cr}_{2} \mathrm{O}_{3}-\mathrm{SiO}_{2}$ system and concluded that chromium oxide reacted with mullite to form rectangular crystals of (Al, $\mathrm{Cr})_{2} \mathrm{O}_{3}$ solid solution, which promoted densification.

Konsztowicz and Boutin [17] performed corrosion tests involving porous, high-alumina refractories in slags and found the refractories to be heavily corroded because of slag penetration through interconnected pores.

Frohlich et al. [18] investigated the influence of the matrix microstructure of highalumina refractories on corrosion resistance and concluded that pore size is important in corrosion by slags.

Kashcheev and Semyannikov [19] studied the influence of porosity of refractories in terms of corrosion resistance and concluded that a reduction in open porosity and pore size leads to a reduction in slag penetration.

Godard et al. [20] tested various refractories in air-fuel and oxy-fuel combustion conditions. Fused cast alumina refractories were found to display maximum physical and chemical stability, whereas silica refractories and many materials containing silicate phases were thermodynamically unstable under the test conditions and showed significant corrosion.

Mukai [21] analyzed the characteristics of the corrosion of silica-based refractory walls by different types of slag films in an inert gas environment. The corrosion of the refractory material at the slag surface was caused by the active motion of the slag film formed by the wettability between the refractory and the slag; the slag film motion accelerated the dissolution rate of the refractory and induced abrasion of the refractories.

Triantafyllidis et al. [22] investigated laser surface-treated high-alumina refractory and found that it had a pore-free, homogeneous surface that was smoother than untreated refractories. 
The laser surface-treated refractory had better corrosion resistance.

In the high-temperature laboratory of the EERC, the coal slag corrosion of monolithic silicon carbide refractory has been studied. The results showed that basic slag corroded SiC refractory bricks more rapidly than acidic slag, and that iron silicides form under reducing conditions [23]. Another bench- and pilot-scale study on chromia-forming alloys at temperatures over $900^{\circ} \mathrm{C}$ [24] showed that although the chromia layers provide excellent protection against corrosion, they partially dissolve into the coal ash or slag during exposure. Also, the slag layer is completely lost on cooling, thereby eliminating it as a protective material. In very high temperature heat exchangers that thermally cycle often, the chromia dissolution may significantly shorten the lifetimes of the materials. In contrast, tests with an alumina-forming alloy at up to $1200^{\circ} \mathrm{C}$ showed that although a small alumina enrichment is observed in the near slag layer, it remains with the alloy on thermal cycling. Therefore, the lifetime of the alloy should not be significantly shortened because of thermal cycling.

\section{EXPERIMENTAL METHODS}

The focus of this project was to test the corrosion resistance of commercially available refractories to flowing slag and propose mechanisms of corrosion for the conditions studied. The primary objective was to carry out well-defined experiments to provide understanding and insight into the performance of refractories under a reducing atmosphere and dynamic slagging condition. Information generated from these experiments will lead to the development of the mechanisms of refractory loss under such an environment. The objective was met by simulating slag-refractory interactions using a bench-scale testing apparatus, the Controlled-Atmospheric Dynamic Corrodent Application Furnace (CADCAF), followed by analysis of the corroded refractory and slag using advanced analytical techniques. 


\subsection{Experimental Apparatus}

The CADCAF was developed on the basis of the dynamic slag application furnace (DSAF) which was operated up to temperatures of $1650^{\circ} \mathrm{C}$ and in the presence of flowing slag for extended periods in an air environment [25]. Compared to the DSAF, the CADCAF has a sealed inner chamber and a gas system, which allows testing of refractories in a controlled atmosphere. The CADCAF and its operation are discussed in more detail by Shukla [26] and Hong [27].

The CADCAF is a bench-scale box furnace with a removable top, made of stainless steel and insulation material. Its structure is illustrated in Figure 3. In the furnace, there is a sealed cylindrical sample container where the refractory brick samples are located. This chamber, including the removable top and bottom plates, is made of 98\% Plicast cement-free castable refractory or of dense $99 \%$ alumina ceramic; the walls are approximately 1 -in. thick. The plates and body are glued together and sealed by moldable alumina cement.

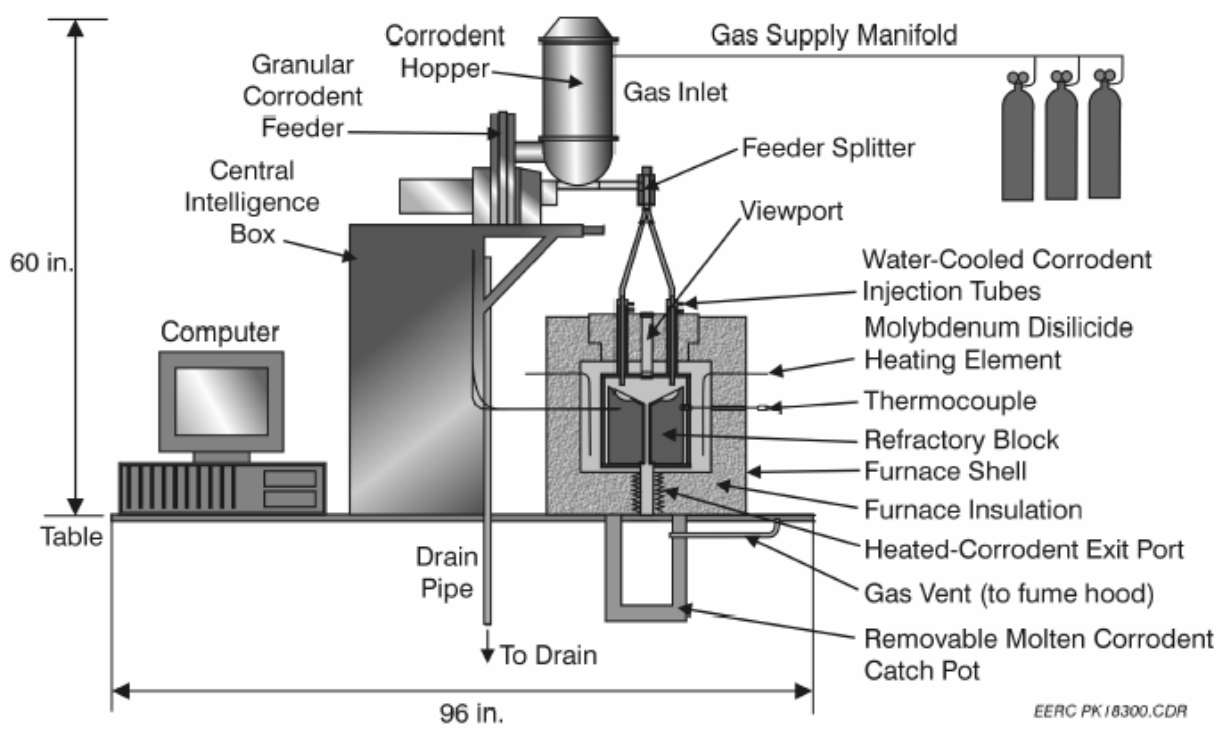

Figure 3. Schematic of the CADCAF 
The CADCAF has the capability of testing two refractory brick samples simultaneously, up to a maximum temperature of $1650^{\circ} \mathrm{C}$. The furnace and the heating system are built by Thermcraft, Inc. The CADCAF is heated by 12 MHI (Micropyretics Heaters International, Inc.) molybdenum disilicide $\left(\mathrm{MoSi}_{2}\right)$ bent heating elements, which are equally installed on all four sidewalls of the furnace. A Yokogawa UP550 controller and a thermocouple control the heating program. In order to avoid crack formation in the sample container, the furnace is heated and cooled at a rate of $1.5^{\circ}$ to $2^{\circ} \mathrm{C} / \mathrm{min}$.

Two slag injector ports enter the inner chamber through two ceramic tubes on the top plate. The injectors are water-cooled stainless steel tubing inside insulated fibers.

A ceramic tube glued to the bottom of the inner chamber acts as the exit port for spent slag. The liquid slag drips through the tube and is collected in a removable insulation materiallined catch pot. A stand with rollers was built to hold the catch pot and allow for easy removal. When the furnace is in operation, the catch pot is clamped and sealed in place to prevent gas leaks. A view port sealed with a piece of glass is located on the vertical sidewall of the pot through which one can watch the slag dripping.

A Hethon ${ }^{\mathrm{TM}}$ feeder above the furnace is used to introduce granulated slag to the refractory bricks. The transfer speed of slag is controlled by the rotation speed of a single feeding screw.

Three different physical designs were used for the refractory brick during this study. They all have a slag-flow channel on the vertical wall and a slag well on the top. Two of them have a 30-degree incline on the top surface; the other one has a flat top. The dimensions of the bricks are shown in Figure 4. 


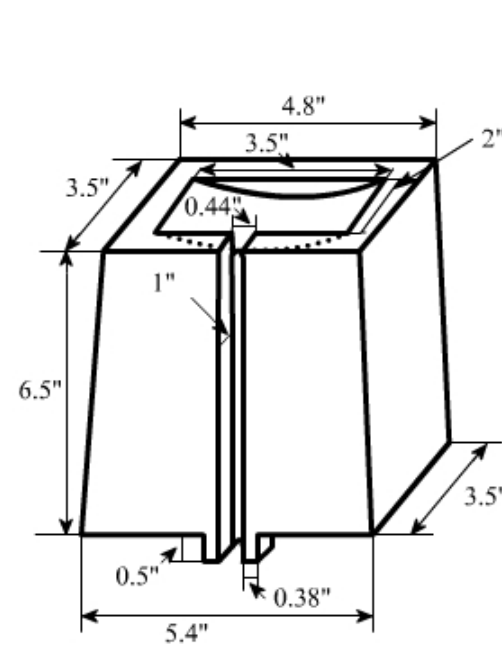

(1)

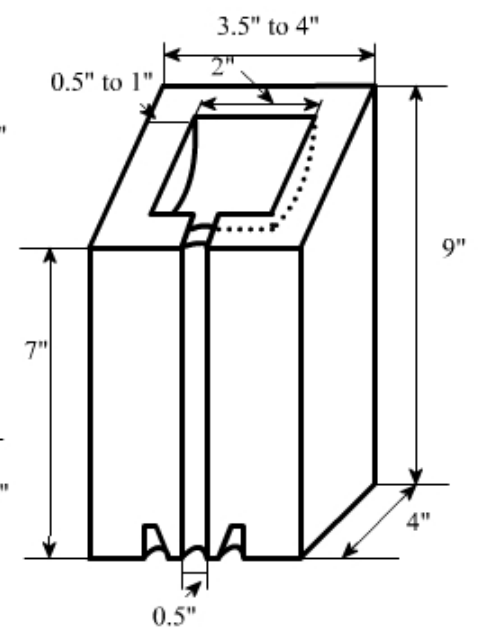

(2)

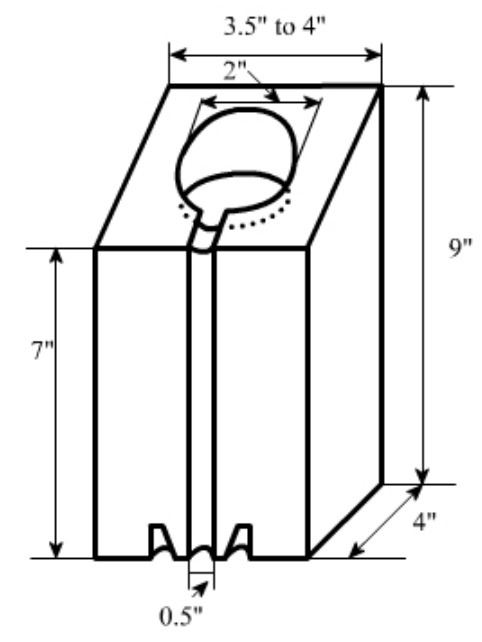

(3)

Figure 4. Refractory Brick Dimensions.

Ideally, to simulate the environment in slagging gasifiers, the exact composition of flue gas should be used for testing. However, due to safety, health hazard concerns, cost, and complexity, $2 \%$ hydrogen in nitrogen was used to simulate the reducing environment. Iron is present in coal in substantial amounts and is affected by the reducing conditions. Hence, it is considered as a reference point in defining the oxygen concentrations within the furnace crucible. Whether an atmosphere is reducing to iron or not, depends on the ratio of water vapor pressure to hydrogen pressure in that atmosphere in accordance to the following:

$$
\mathrm{FeO}+\mathrm{H}_{2} \rightarrow \mathrm{Fe}+\mathrm{H}_{2} \mathrm{O} \quad \text { and } \quad K=\frac{p_{\mathrm{H}_{2} \mathrm{O}}}{p_{\mathrm{H}_{2}}}
$$

The equilibrium constant is a function of temperature as represented in Figure 5. At a temperature of $1500^{\circ} \mathrm{C}$, the ratio is 1.045 indicating that atmospheres with $\mathrm{H}_{2} \mathrm{O} / \mathrm{H}_{2}$ ratios up to 1.045 are reducing. The water formed is entirely due to the reaction between hydrogen and oxygen that may be present in the gas. Hence, the water-to-hydrogen ratio is in effect oxygen-to-hydrogen ratio. This has been the logic behind maintaining the reducing atmosphere in the CADCAF. 


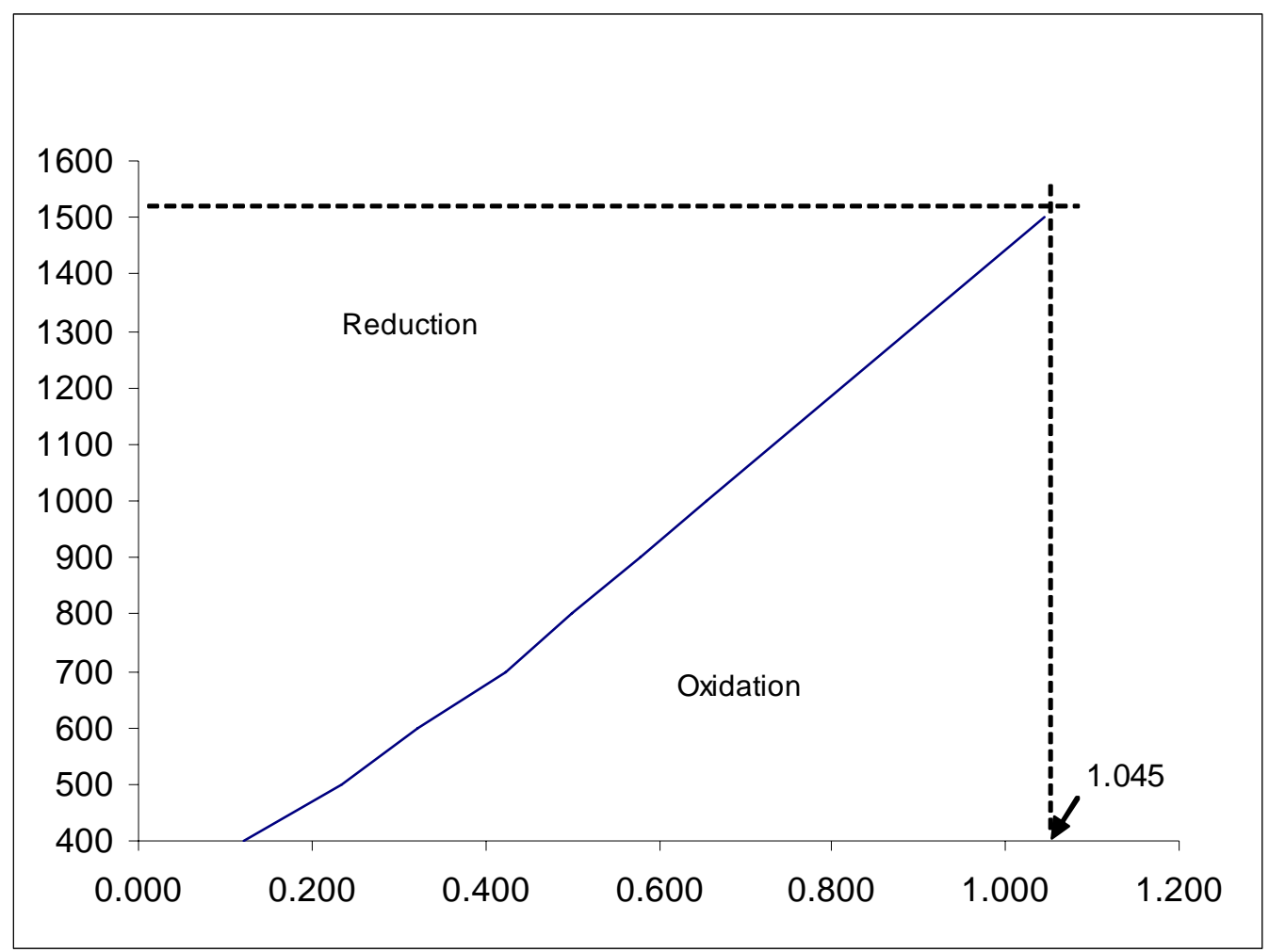

Figure 5. Ratio of $\mathrm{H}_{2} \mathrm{O} / \mathrm{H}_{2}$ partial pressures to temperature

The scheme of the gas control system is shown in Figure 6. The key parts of this system are the hydrogen sensor, data processing hardware (ADAM5000 data acquisition module) and software (LabTech 12.1), and the solenoid valve. When the CADCAF is in operation, the appropriate amount of hydrogen and nitrogen $(10 \mathrm{~L} / \mathrm{min})$ is mixed within a mixing chamber. Between the mixing chamber and the sample container, an electrochemical hydrogen sensor continually measures the hydrogen concentration; if the hydrogen concentration is higher than $2 \%$, the sensor generates a warning signal and to the data acquisition module. Simultaneously, the LabTech program-controlled module switches off the hydrogen solenoid valve, and the hydrogen concentration goes down. When the hydrogen concentration is lower than $2 \%$, the valve will be switched on again by the program. At the same time, the space between the furnace and the sample container is purged by nitrogen $(10 \mathrm{~L} / \mathrm{min})$. In this way, the system keeps a stable atmosphere in the sample container that is reducing relative to iron. 


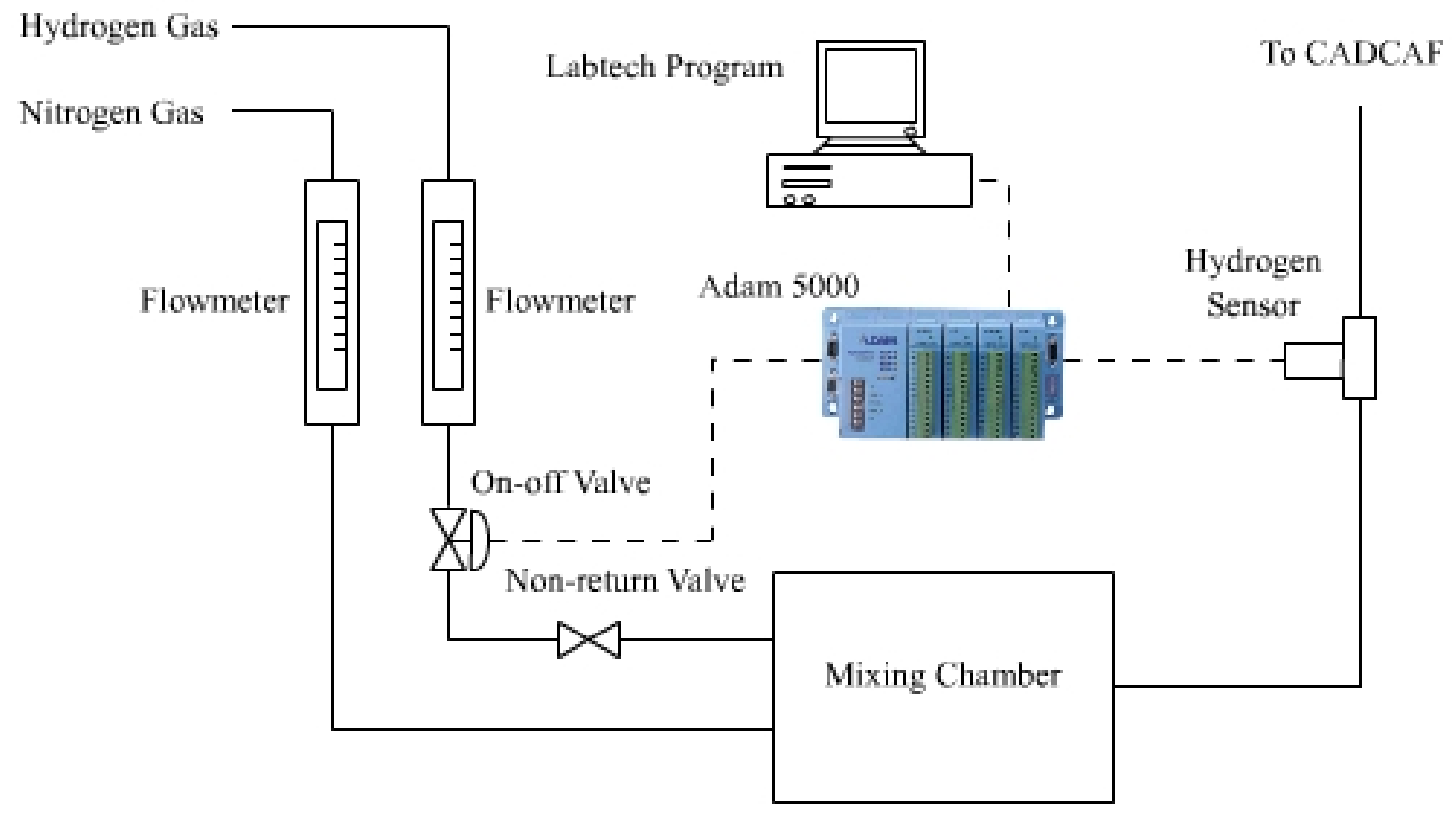

Figure 6. Scheme of CADCAF Gas System.

During the early experiments, the pressure drop was very high in the system. In order to reduce the pressure drop and get a better gas-flowing condition for the testing, the gas mixture was introduced into the inner chamber through one of the slag injectors directly instead of through the slag feeder as shown in Figure 3. At the same time, the slag feeder was purged by nitrogen gas. Therefore, although the CADCAF has the capability of testing two brick samples simultaneously, only one brick has been tested in each experiment.

In the early experiments, slag bounced out of the slag well, contaminated the inner chamber, and caused exit tube plugging. Therefore, ceramic shields, as shown in Figure 7, have been used as a screen for the bouncing slag. A small alumina rod is glued to the shield to keep it on the inclined brick top. The shield was successful in keeping the slag in the well. There is some concern about slag interacting with the shield. This will be discussed in the results section. 


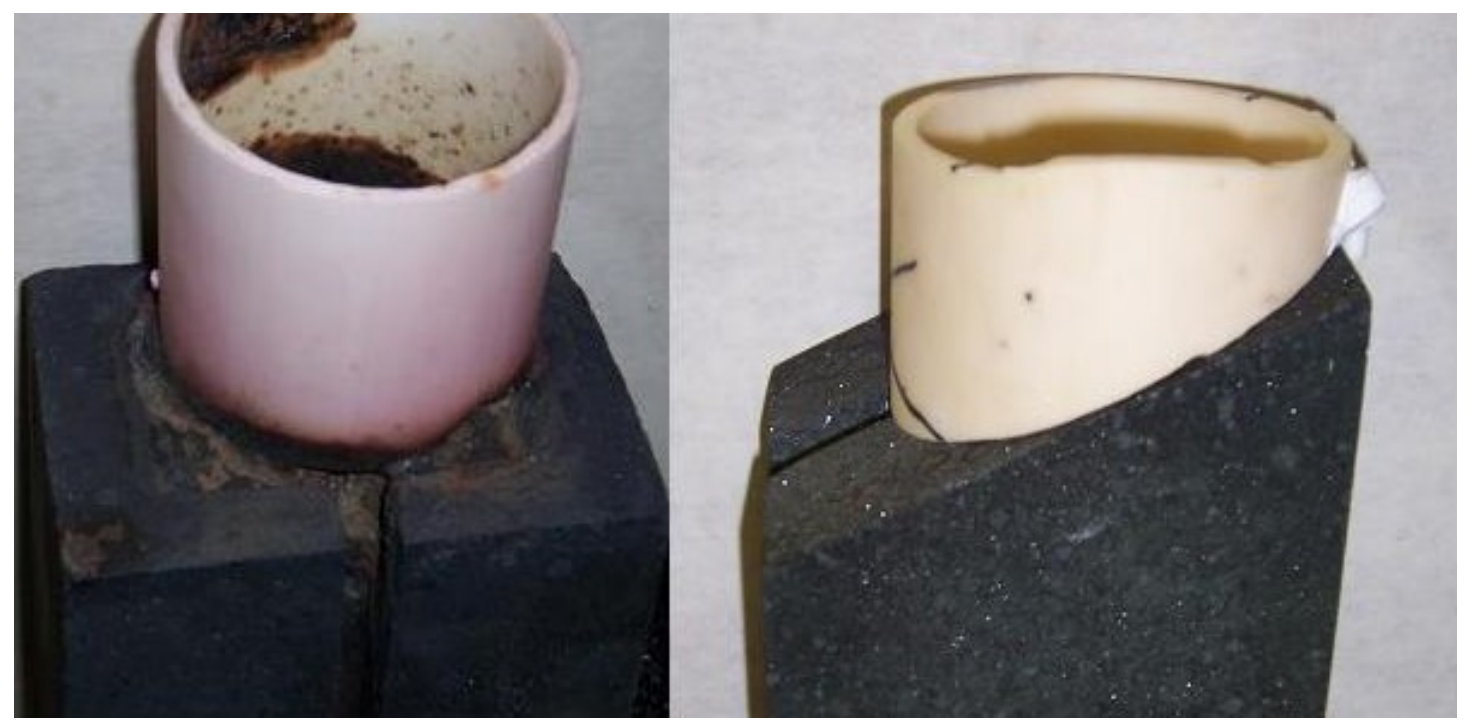

Figure 7. Slag Shields.

\subsection{Analysis of the Refractory and Slag}

Before the CADCAF tests, the porosity of some of the refractories were measured. The method used is similar to guidelines from the ASTM C20 standard.

The brick recessions were measured by comparing the brick thickness before and after the test. Three points along the slag-flow channel were chosen for the measurement. They were located 1 inch from the channel top, at the center of the channel, and 1 inch from the channel bottom.

After exposure to the flowing slag, the bricks were cut to half along the slag-flowing channel for cross-sectional investigations. Two tested bricks were then sliced and polished for scanning electron microscopy (SEM) analysis to determine the slag penetration and changes in refractory microstructure. (Note: In the SEM analysis, the oxygen signal was strongly disturbed; therefore, the SEM data was normalized to a non-oxygen basis.)

The spent slag from each test was also collected. Several slag drops from different places in the catch pot were mixed and granulated for the Rigaku wavelength-dispersive x-ray 
fluorescence (WDXRF) analysis. The detection limit is $0.01 \mathrm{wt} \%$. The slag elemental concentrations ( $\mathrm{Si}, \mathrm{Al}, \mathrm{Fe}, \mathrm{Ca}, \mathrm{Mg}$, etc.) were characterized to determine the slag composition change.

\section{RESULTS AND DISCUSSION}

\subsection{Brick and Slag Analysis}

The refractories tested in this study were obtained from two commercial companies.

Table 1 and Figure 8 show the main constituents and the apparent porosity of the refractories.

The data indicate that the refractory porosity is independent of any of the main constituents.

Table 1. Basic Information of the Refractories.

\begin{tabular}{c|c|cc}
\hline \multicolumn{2}{c}{ Refractories } & Major Constituents & $\begin{array}{c}\text { Apparent } \\
\text { Porosity, \% }\end{array}$ \\
\hline & I & Alumina bonded and alumina/spinel & $/$ \\
& BPMG & Alumina bonded and alumina/spinel & $/$ \\
Blasch Co. & BPMGS & Alumina bonded and alumina/spinel & $25.5^{1}$ \\
& A20 & 75.7\% alumina, 19.1\% chromia, 1.6\% silica & $17.5^{2}$ \\
& A90 & 4.3\% alumina, 95.3\% chromia, 0.2\% silica & $15.1^{2}$ \\
\hline Tampa Co. & T & 16.2\% alumina, 79.8\% chromia, 3.1\% silica & $10.1^{1}$ \\
\hline
\end{tabular}

${ }^{1}$ Tested in the EERC lab (ASTM C20).

${ }^{2}$ Company's product information.

Slags used to test the refractory stability were from two solid fuel gasifiers. Before the experiments, they were pulverized and sieved to -20 to +60 mesh. The compositions of the slags have been analyzed by WDXRF and are shown in Table 2. B/A ratios are calculated according to Eq. 1. The data show that Slag B is more basic than Slag A.

$$
B / A=\frac{\mathrm{Fe}_{2} \mathrm{O}_{3}+\mathrm{CaO}+\mathrm{MgO}+\mathrm{K}_{2} \mathrm{O}+\mathrm{Na}_{2} \mathrm{O}}{\mathrm{SiO}_{2}+\mathrm{Al}_{2} \mathrm{O}_{3}+\mathrm{TiO}_{2}}
$$




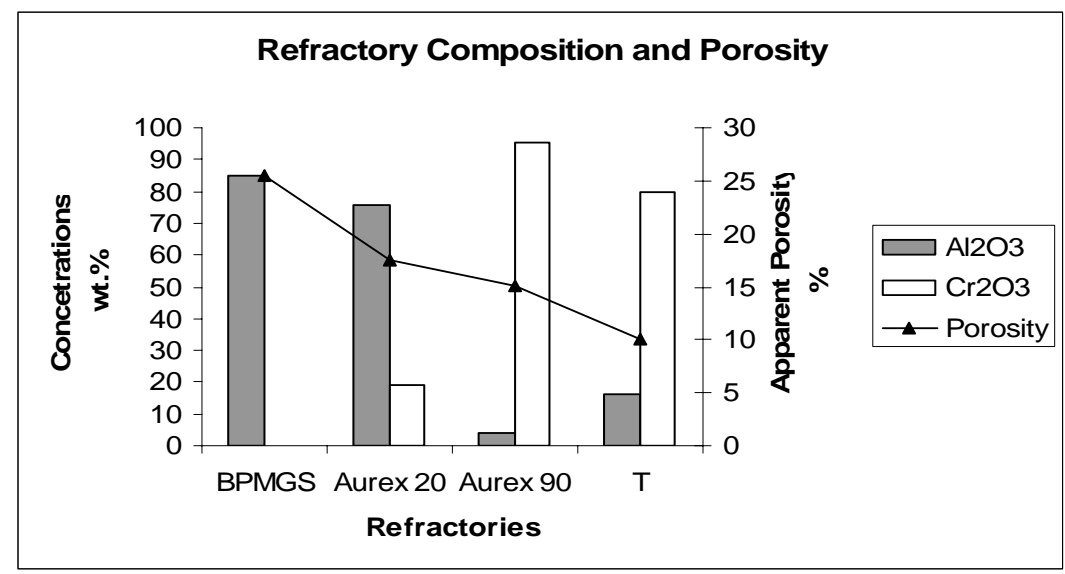

Figure 8. Refractory Composition and Porosity (assuming the BPMGS brick contains 85 wt\% of alumina and $0 \mathrm{wt} \%$ of chromia).

Table 2. WDXRF Analysis of Slag A and Slag B, wt\%.

\begin{tabular}{ccc|ccc}
\hline Oxides & Slag A & Slag B & Element & Slag A & Slag B \\
\hline $\mathrm{SiO}_{2}$ & 49.6 & 36.6 & $\mathrm{Si}$ & 42.4 & 30.7 \\
$\mathrm{Al}_{2} \mathrm{O}_{3}$ & 17.3 & 17.9 & $\mathrm{Al}$ & 16.7 & 16.6 \\
$\mathrm{Fe}_{2} \mathrm{O}_{3}$ & 12.1 & 34.7 & $\mathrm{Fe}$ & 15.5 & 42.4 \\
$\mathrm{CaO}$ & 5.1 & 2.3 & $\mathrm{Ca}$ & 6.7 & 2.8 \\
$\mathrm{MgO}$ & 1.6 & 0.9 & $\mathrm{Mg}$ & 1.7 & 0.9 \\
$\mathrm{Na}_{2} \mathrm{O}$ & 5.1 & 0.7 & $\mathrm{Na}$ & 6.9 & 0.9 \\
$\mathrm{~K}_{2} \mathrm{O}$ & 2.0 & 2.1 & $\mathrm{~K}$ & 3.1 & 3.0 \\
$\mathrm{~V}_{2} \mathrm{O}_{5}$ & 4.3 & 0.0 & $\mathrm{~V}$ & 4.4 & 0.0 \\
$\mathrm{Cr}_{2} \mathrm{O}_{3}$ & 0.1 & 0.0 & $\mathrm{Cr}$ & 0.08 & 0.0 \\
\hline $\mathrm{B} / \mathrm{A} \mathrm{ratio}$ & 0.38 & 0.7 & & & \\
\hline
\end{tabular}

\subsection{CADCAF Tests}

A total of four refractory brick types have been tested in this study. The brick types include two high-alumina bricks and two high-chromia bricks. Table 3 lists the experimental conditions and the combinations of refractory and slag. At $1400^{\circ} \mathrm{C}$ no slag dripping was observed in the "Brick I + Slag B" test, which means there was no flowing slag in the test. The temperature was gradually raised until slag dripping was seen at $1475^{\circ} \mathrm{C}$. 
Table 3. CADCAF Tests.

\begin{tabular}{ccccc}
\hline Bricks & Slag & $\begin{array}{c}\text { Slag Feeding Rate, } \\
\text { g/min }\end{array}$ & Temp., ${ }^{\circ} \mathrm{C}$ & $\begin{array}{c}\text { Total Time Tested, } \\
\text { h }\end{array}$ \\
\hline I & A & 51 & 1400 & 28 \\
I & B & 51 & 1475 & 23 \\
BPMG & A & 51 & 1400 & 30 \\
BPMG & B & 51 & 1400 & 30 \\
A90 & B & 51 & 1400 & 30 \\
T & A & 60 & 1425 & $62\left(33^{\mathrm{Ta}}+29^{\mathrm{Tb}}\right)$ \\
\hline
\end{tabular}

${ }^{\mathrm{T}}$ Without slag shield.

${ }^{\mathrm{Tb}}$ With slag shield.

Alumina shields were used to keep the slag in the well, and there was some concern that the shield might release aluminum into the slag and cause inaccurate results. To determine the shield's influence on the CADCAF test, the spent slags from both Ta and Tb tests have been examined (Table 4). Since no significant difference was found when comparing the composition of the two slags, composition, the shield's effects on these tests were ignored.

During all of the experiments, white ash deposited on the view port glass. The white ash is silicon monoxide ( $\mathrm{SiO}$ ) and is a reduction product of $\mathrm{SiO}_{2}$ by hydrogen [8, 28]. The appearance of white ash indicates that the experiments were carried out in a reducing atmosphere.

Table 4. The Influence of the Alumina Shield on the CADCAF Test.

\begin{tabular}{cccc}
\hline Element, wt\% & $\mathrm{Ta}$ & $\mathrm{Tb}$ & Difference \\
\hline $\mathrm{Si}$ & 41.5 & 41.8 & $-0.7 \%$ \\
$\mathrm{Al}$ & 18.0 & 17.0 & $5.6 \%$ \\
$\mathrm{Fe}$ & 15.4 & 15.7 & $-1.9 \%$ \\
$\mathrm{Ca}$ & 6.7 & 6.7 & $0.0 \%$ \\
$\mathrm{Mg}$ & 1.7 & 1.8 & $-5.9 \%$ \\
\hline
\end{tabular}


Figures 9 and 10 show the front face and cross section of the tested bricks. The refractory recessions along the channel were characterized and presented in Figure 11. The graphs clearly show that Brick A90 has the best corrosion resistance in the CADCAF test, followed by Brick T. The high-aluminum bricks (I and BPMG) are much worse. The results suggest that the higher the

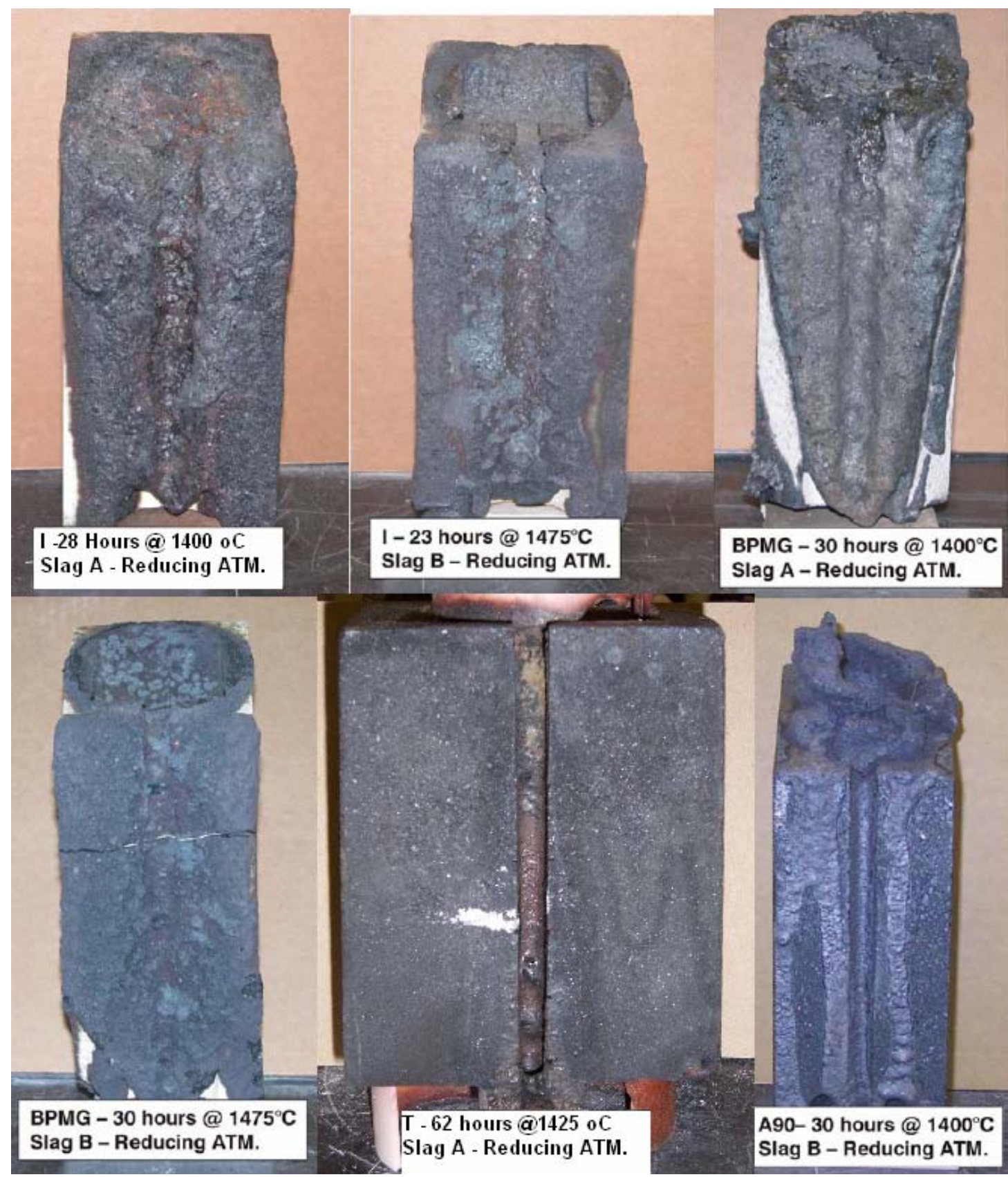

Figure 9. Bricks after the CADCAF Test. 


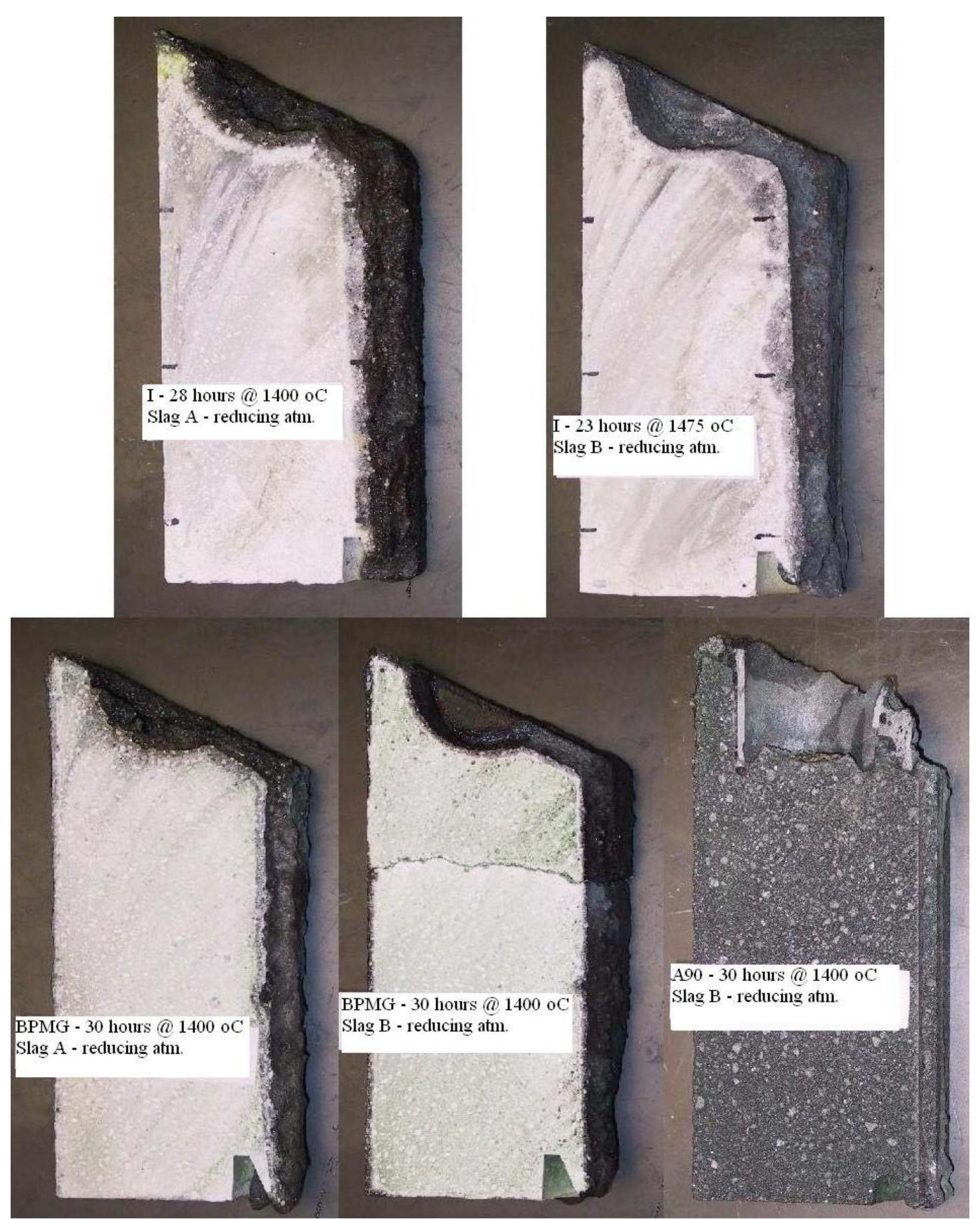

Figure 10. Cross Section of the Tested Bricks (note: Brick A90 has a different slag well [refer to Figure 5], and the slag shield is stuck to the brick after testing).

chrome concentration in the refractory, the better the refractory's resistance. This is consistent with the results of previous studies [7,8,13,15]. For a given brick, Slag A dissolved more 
refractory than slag B in the tests. The reasons for this phenomenon will be discussed later. In addition, during the test, slags penetrated into all of the bricks. In some of them, the penetration can be divided into two layers—-black and white.

An interesting phenomenon noticed was that the surface recession at the bottom of most of the refractory bricks was less than at the top (Table 5). This suggests that when the slag dissolves some of the refractory, it may become less corrosive. One possible method of reducing slag corrosion may be saturating it with refractory additives. This has been proved in a previous study [25].

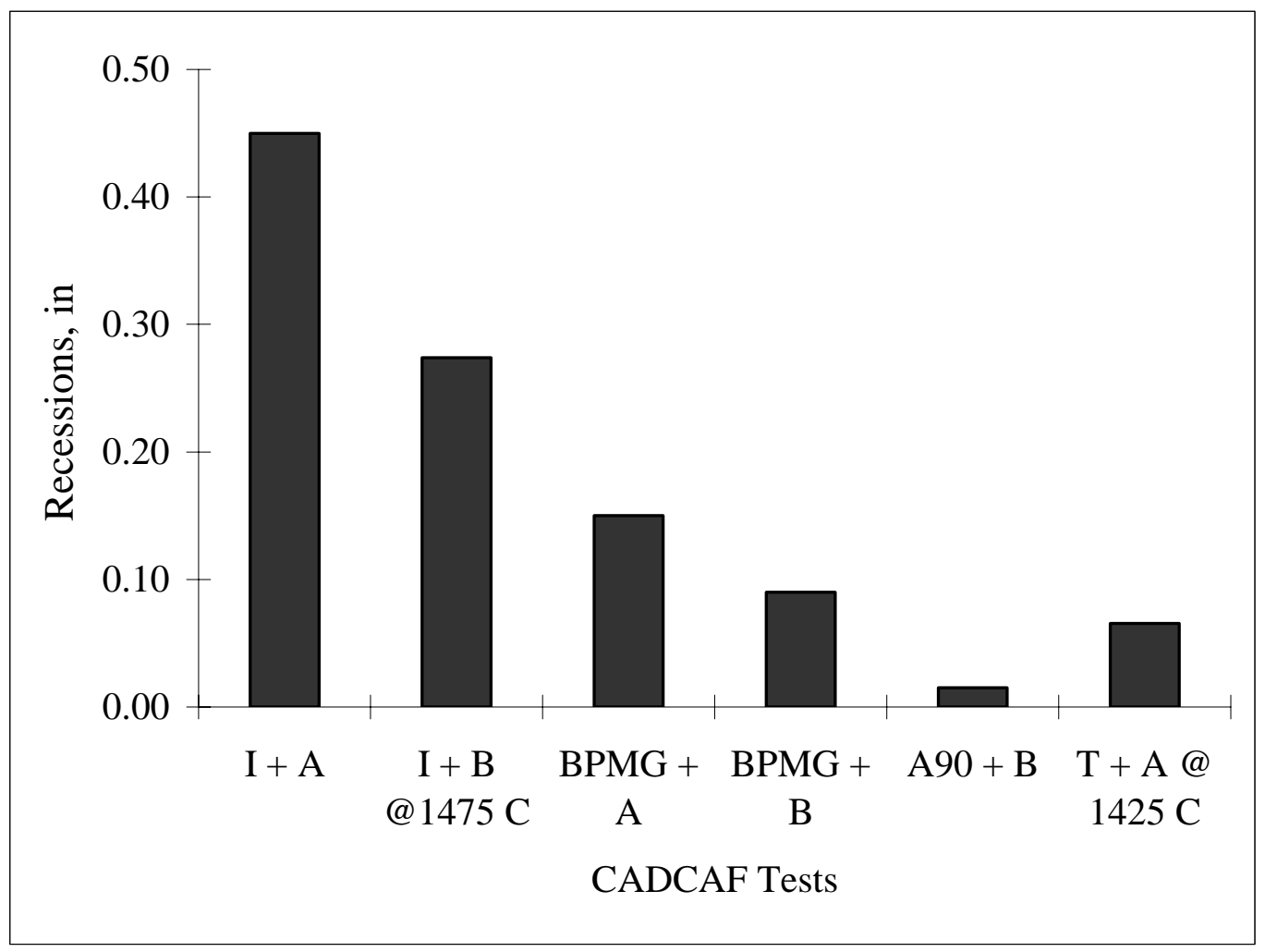

Figure 11. Brick Recessions Verses Time (normalized to a 30-hour basis). 
Table 5. Brick Recession along the Slag Flowing Channel, inch.

\begin{tabular}{lcccccc}
\hline & \multicolumn{1}{c}{ I } & \multicolumn{2}{c}{ BPMG } & A 90 & Tampa $^{\text {[31] }}$ \\
\hline \multicolumn{1}{c}{ Slag used } & A & B & A & B & A & A \\
\hline $\begin{array}{l}1 \text { in. from the } \\
\text { Channel Top }\end{array}$ & 0.45 & 0.33 & 0.23 & 0.14 & 0.016 & 0.07 \\
$\begin{array}{l}\text { Center of the } \\
\text { Channel }\end{array}$ & 0.45 & 0.22 & 0.14 & 0.11 & 0.012 & 0.07 \\
$\begin{array}{l}1 \text { in. from the } \\
\text { Channel Bottom }\end{array}$ & 0.40 & 0.04 & 0.08 & 0.05 & 0.006 & 0.08 \\
\hline
\end{tabular}

\subsection{SEM Analysis}

SEM analysis was used to help understand the slag-refractory interaction. The BPMG bricks were selected for this analysis. Figure 12 and Table 6 provide the structure and elemental composition of the untreated BPMG refractory matrix. The results show that the matrix is rich in alumina and magnesia, and also contains traces other elements, e.g. K, $\mathrm{Na}, \mathrm{Ca}, \mathrm{Si}, \mathrm{S}$ and $\mathrm{Cl}$.

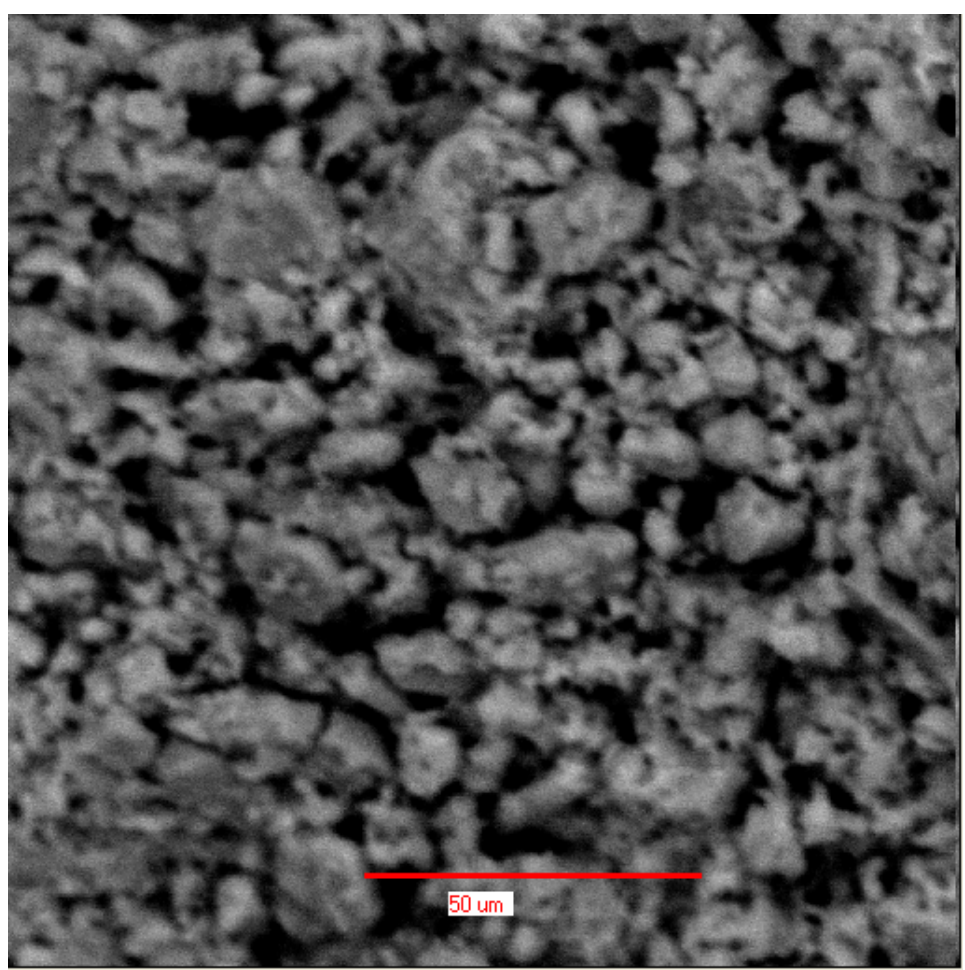

Figure 12. SEM Micrographs of the Initial Matrix of BPMG Brick. 
Table 6. SEM Elemental Analysis of the Initial Matrix of BPMG Brick, wt\%.

\begin{tabular}{ccccccccccccccc}
\hline $\mathrm{Na}$ & $\mathrm{Mg}$ & $\mathrm{Al}$ & $\mathrm{Si}$ & $\mathrm{P}$ & $\mathrm{S}$ & $\mathrm{Cl}$ & $\mathrm{K}$ & $\mathrm{Ca}$ & $\mathrm{Ti}$ & $\mathrm{Cr}$ & $\mathrm{Fe}$ & $\mathrm{Ba}$ & $\mathrm{Ni}$ & $\mathrm{V}$ \\
\hline 0.6 & 14.8 & 70.0 & 3.8 & 0.0 & 2.5 & 1.0 & 3.3 & 4.0 & 0.0 & 0.0 & 0.0 & 0.0 & 0.0 & 0.0 \\
\hline
\end{tabular}

Below the interface of Sample A, two different phases were observed. One has a high concentration of aluminum and trace silicon (Figure 13, Sample A, Points 9 and 10); it is the refractory grain. In the test, refractory grains showed strong resistance to the slag corrosion, acting as the first line of defense against corrosion [29]. The other phase is the matrix, where the slag infused through it (Figure 13, Sample A, Points 5, 6, 7, and 8). It is rich in $\mathrm{Si}, \mathrm{Al}$, and $\mathrm{Ca}$ (named phase $\mathrm{Al}-\mathrm{Si}$ ), and small quantities of $\mathrm{Na}, \mathrm{Mg}$, and $\mathrm{K}$ were also detected. The elemental composition suggests that this is a phase based on aluminosilicate, and it can be expressed as $\mathrm{M}_{\mathrm{x}} \mathrm{AlSi}_{2.2} \mathrm{O}_{\mathrm{y}}(\mathrm{M}=\mathrm{Ca}, \mathrm{Mg}, \mathrm{K}$, and $\mathrm{Na})$. With depth into the refractory, there are still only the aluminosilicate phase and alumina grains detected.

Among the penetrated elements, calcic compounds have been widely used as fluxing agents in gasification operation [30]. They could dissolve the refractory by reacting with the refractory and forming lower viscosity compounds. The dissolution of refractory by $\mathrm{CaO}$ has also been reported in a high-chrome refractories study [13]. The results from this study and the cited study [13] show that $\mathrm{CaO}$ in the slag, even at concentrations as low as 4 to $7 \mathrm{wt} \%$, can affect the integrity of the refractory surface layer. Alkalis in the slag also penetrate into the alumina refractory and react with its components to form low melting compounds such as nepheline $\left[(\mathrm{Na}, \mathrm{K}) \mathrm{AlSiO}_{4}\right]\left(1370^{\circ} \mathrm{C}\right)$, kalsilite $\left(\mathrm{KAlSiO}_{4}\right)$, leucite $\left(\mathrm{KAlSi}_{2} \mathrm{O}_{6}\right)\left(1262^{\circ} \mathrm{C}\right)$ and albite $\left(\mathrm{NaAlSi}_{3} \mathrm{O}_{10}\right)\left(1175^{\circ} \mathrm{C}\right)$, which have significantly larger volume than the volume of the original phase [31]. The volume mismatch could cause severe refractory degradation during the cooling stage. 

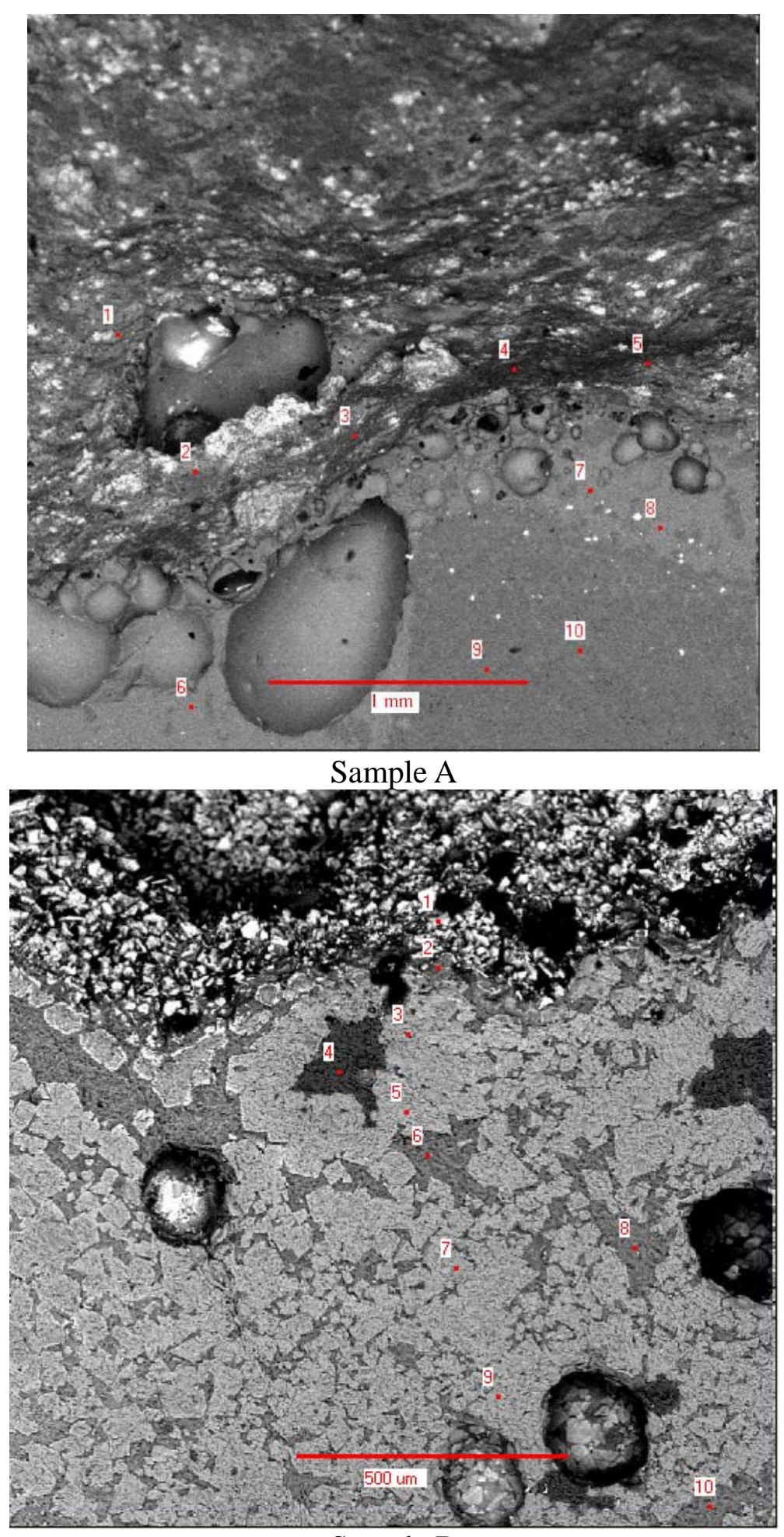

Sample B

Figure 13. SEM Micrographs of the Cross Section of the BPMG Bricks. Sample A, Corroded by Slag A; Sample B, Corroded by Slag B. Analysis of the points are given in Tables 7 and 8. 
Table 7. SEM Elemental Analysis of Brick BPMG Corroded by Slag A, wt\%. Refer to Figure 12 for location of the points given in the analysis.

\begin{tabular}{cccccccccccccc}
\hline Point & Phase & $\mathrm{Na}$ & $\mathrm{Mg}$ & $\mathrm{Al}$ & $\mathrm{Si}$ & $\mathrm{S}$ & $\mathrm{K}$ & $\mathrm{Ca}$ & $\mathrm{Ti}$ & $\mathrm{Cr}$ & $\mathrm{Fe}$ & $\mathrm{Ni}$ & $\mathrm{V}$ \\
\hline 1 & Surface & 0.9 & 2.1 & 20.4 & 41.5 & 0.7 & 3.1 & 21.8 & 0.0 & 2.0 & 7.5 & 0.0 & 0.0 \\
2 & Surface & 0.8 & 1.4 & 47.0 & 34.6 & 0.0 & 1.4 & 14.7 & 0.0 & 0.0 & 0.0 & 0.0 & 0.0 \\
3 & Interface & 0.7 & 4.7 & 16.3 & 29.9 & 0.0 & 1.2 & 29.0 & 0.0 & 0.0 & 12.9 & 0.0 & 5.3 \\
4 & Interface & 1.0 & 1.6 & 20.9 & 39.3 & 0.0 & 2.4 & 22.3 & 0.0 & 0.0 & 9.5 & 0.0 & 2.9 \\
5 & Al-Si & 1.4 & 1.7 & 26.2 & 40.9 & 0.0 & 4.7 & 25.2 & 0.0 & 0.0 & 0.0 & 0.0 & 0.0 \\
6 & Al-Si & 1.2 & 1.6 & 22.6 & 48.2 & 1.0 & 6.2 & 19.2 & 0.0 & 0.0 & 0.0 & 0.0 & 0.0 \\
7 & Al-Si & 1.0 & 1.9 & 19.9 & 51.2 & 1.2 & 7.3 & 17.5 & 0.0 & 0.0 & 0.0 & 0.0 & 0.0 \\
8 & Al-Si & 1.0 & 1.4 & 19.2 & 50.7 & 0.0 & 7.3 & 20.4 & 0.0 & 0.0 & 0.0 & 0.0 & 0.0 \\
9 & Grain & 0.0 & 0.0 & 98.2 & 2.0 & 0.0 & 0.0 & 0.0 & 0.0 & 0.0 & 0.0 & 0.0 & 0.0 \\
10 & Grain & 0.0 & 0.0 & 100 & 0.0 & 0.0 & 0.0 & 0.0 & 0.0 & 0.0 & 0.0 & 0.0 & 0.0 \\
\hline
\end{tabular}

Table 8. SEM Elemental Analysis of Brick BPMG Corroded by Slag B, wt\%. Refer to Figure 13 for location of the points given in the analysis.

\begin{tabular}{cccccccccccccc}
\hline Point & Phase & $\mathrm{Na}$ & $\mathrm{Mg}$ & $\mathrm{Al}$ & $\mathrm{Si}$ & $\mathrm{S}$ & $\mathrm{K}$ & $\mathrm{Ca}$ & $\mathrm{Ti}$ & $\mathrm{Cr}$ & $\mathrm{Fe}$ & $\mathrm{Ni}$ & $\mathrm{V}$ \\
\hline 1 & Interface & 0.0 & 0.2 & 3.0 & 0.0 & 0.0 & 0.0 & 0.0 & 0.0 & 0.0 & 96.9 & 0.0 & 0.0 \\
2 & Al-Si & 1.6 & 0.0 & 14.3 & 45.6 & 0.0 & 16.3 & 7.6 & 0.0 & 0.0 & 14.6 & 0.0 & 0.0 \\
3 & Spinel & 0.0 & 2.1 & 28.1 & 0.0 & 0.0 & 0.0 & 0.0 & 0.0 & 2.5 & 67.4 & 0.0 & 0.0 \\
4 & Grain & 0.0 & 0.0 & 100.0 & 0.0 & 0.0 & 0.0 & 0.0 & 0.0 & 0.0 & 0.0 & 0.0 & 0.0 \\
5 & Spinel & 0.0 & 1.9 & 26.4 & 0.0 & 0.0 & 0.0 & 0.0 & 0.0 & 2.1 & 69.7 & 0.0 & 0.0 \\
6 & Al-Si & 0.6 & 0.0 & 12.5 & 40.6 & 0.0 & 3.8 & 11.3 & 0.0 & 0.0 & 31.1 & 0.0 & 0.0 \\
7 & Spinel & 0.0 & 2.6 & 30.2 & 0.0 & 0.0 & 0.0 & 0.0 & 0.0 & 1.7 & 65.6 & 0.0 & 0.0 \\
8 & Al-Si & 0.7 & 0.5 & 13.6 & 40.4 & 0.4 & 3.9 & 9.1 & 2.8 & 0.0 & 28.5 & 0.0 & 0.0 \\
9 & Spinel & 0.0 & 1.6 & 22.6 & 0.0 & 0.0 & 0.0 & 0.0 & 0.0 & 1.8 & 74.0 & 0.0 & 0.0 \\
10 & Al-Si & 0.0 & 0.5 & 13.5 & 41.5 & 0.0 & 5.3 & 12.0 & 3.4 & 0.0 & 23.6 & 0.0 & 0.0 \\
\hline
\end{tabular}

As to Sample B, three phases were found below the interface. The alumina grains still showed strong resistance to the slag (Figure 13, Sample B, Point 4); only trace silicon is found in them. The second phase has a grain-like shape (Figure 13, Sample B, Points 2, 6, 8, and 10), but its elemental composition is similar to the Al-Si phase found in Sample A, except it also contains titanium and a high iron concentration. The composition suggests this is an aluminosilicate phase 
with a general chemical formula of $\mathrm{M}_{\mathrm{x}} \mathrm{AlSi}_{3} \mathrm{O}_{\mathrm{y}}(\mathrm{M}=\mathrm{Fe}, \mathrm{Mg}, \mathrm{Na}, \mathrm{Ca}, \mathrm{K}$, and Ti). The third phase is prevalent in the area just below the slag-refractory interface (Figure 13, Sample B, Points 3, 5, 7, and 9). It is rich in Fe and also has $\mathrm{Al}$ and small concentrations of $\mathrm{Mg}$ and $\mathrm{Cr}$. This is a typical spinel composition, mainly containing $(\mathrm{Fe}, \mathrm{Al})_{3} \mathrm{O}_{4}$ and small quantities of $(\mathrm{Fe}, \mathrm{Cr})_{3} \mathrm{O}_{4},(\mathrm{Mg}$, $\mathrm{Al})_{3} \mathrm{O}_{4}$, and $(\mathrm{Mg}, \mathrm{Cr})_{3} \mathrm{O}_{4}$. The formation of this phase results from iron oxide in the slag reacting with the alumina sesquioxide in the refractory, with $\mathrm{Cr}$ replacing some of the $\mathrm{Al}$ and $\mathrm{Mg}$ replacing some of the $\mathrm{Fe}[23]$. The spinel phase has a high melting temperature; e.g. $(\mathrm{Fe}, \mathrm{Al})_{3} \mathrm{O}_{4}$, $(\mathrm{Mg}, \mathrm{Al})_{3} \mathrm{O}_{4},(\mathrm{Fe}, \mathrm{Cr})_{3} \mathrm{O}_{4}$, and $(\mathrm{Mg}, \mathrm{Cr})_{3} \mathrm{O}_{4}$ have melting temperatures of $1780^{\circ} \mathrm{C}, 2135^{\circ} \mathrm{C}$, $2150^{\circ} \mathrm{C}$, and $2450^{\circ} \mathrm{C}$, respectively [23]. This means that this phase is stable at the experimental temperature and could act as a barrier to ingress of the slag, so no other elements were detected in it.

The comparison of the two samples indicates that calcium and alkalis in the slag are more corrosive than iron. Calcium and alkali compounds react with refractory and form low melting products, while iron compounds and the refractory form a high melting spinel phase. Slag A has much higher calcium and alkali contents than Slag B, which is why the Slag A tested refractories have recessed more than the Slag B tested ones (refer to Figures 9 and 10).

As the infusion depth into the refractory increases, there are only two phases visible (Figure 14, c and d), while the elemental composition analysis suggests there are three different microstructures (Tables 11 and 12). This is probably because when slag penetrated into the refractory, it reacted with the matrix, and the products formed a mixture of aluminosilicate and spinel. Once the reactions were completed, the two solid phases began to crystallize, then aluminosilicate and spinel separated, as was seen at a lower depth below the interface. 


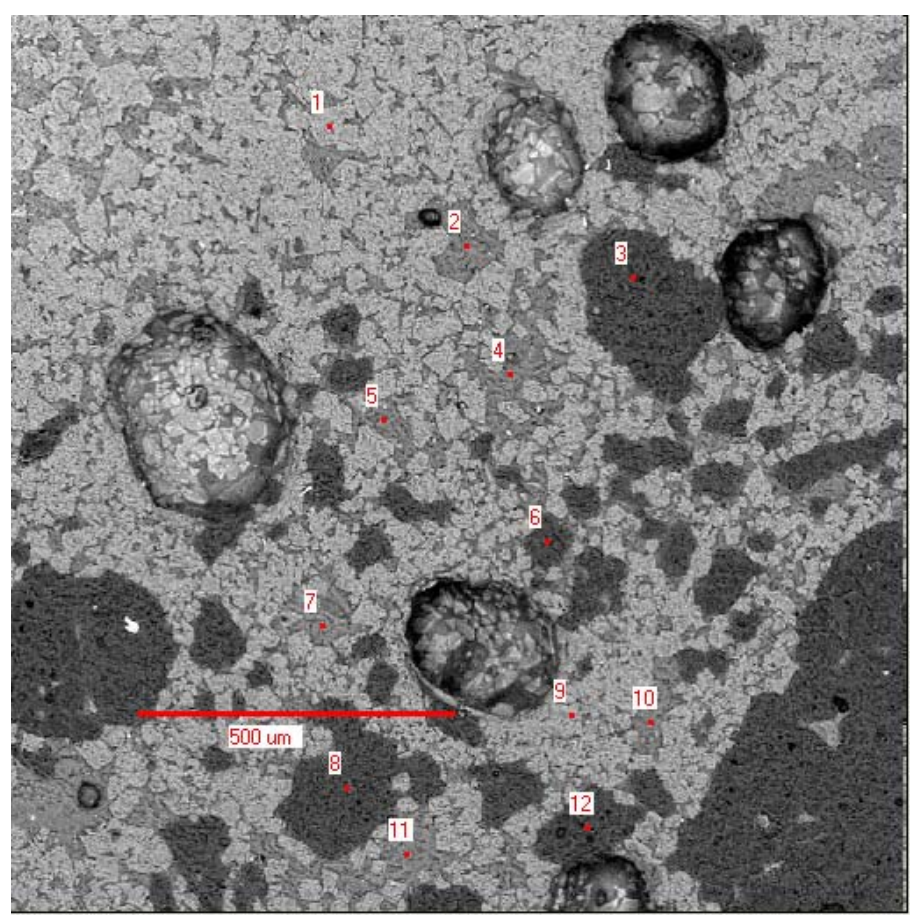

a

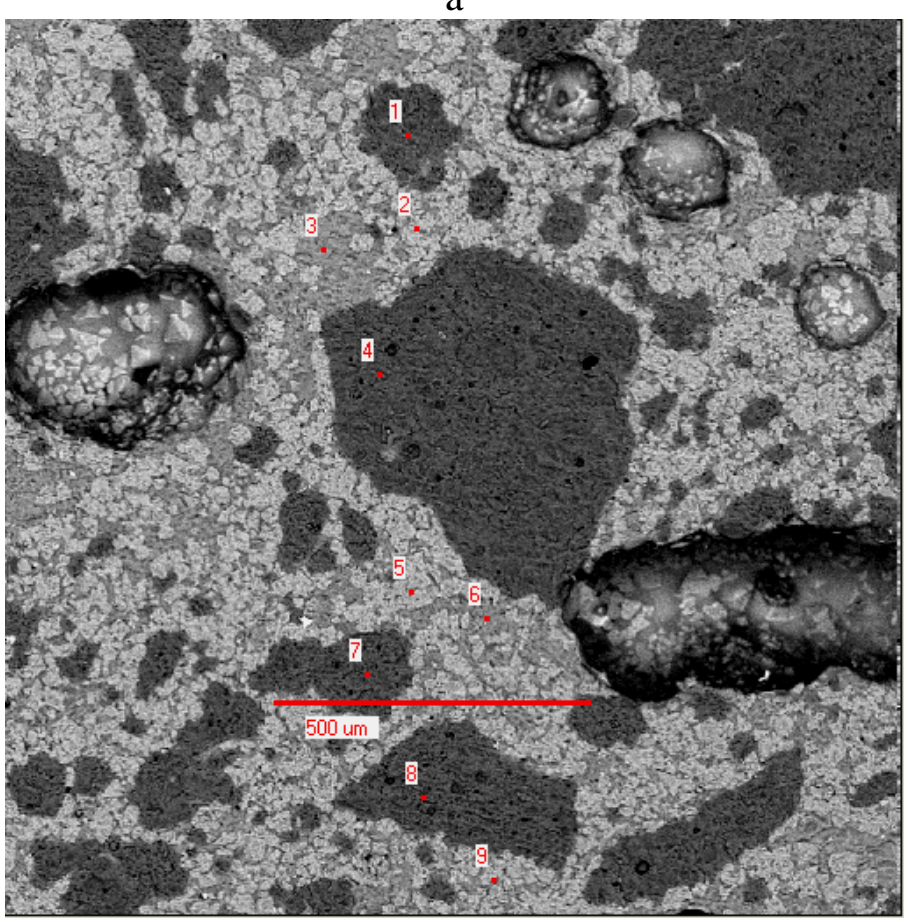

b

Figure 14. SEM Micrographs of the Cross Section of the BPMG Brick Tested by Slag B: (a) 1 to $2.5 \mathrm{~mm}$ below the Interface; (b) 2.5 to $4 \mathrm{~mm}$ below Interface; (c) 4 to $5.5 \mathrm{~mm}$ below the Interface; and (d) 5.5 to $7 \mathrm{~mm}$ below Interface (See Tables 9, 10, 11 and 12 for the analysis of the Points). 


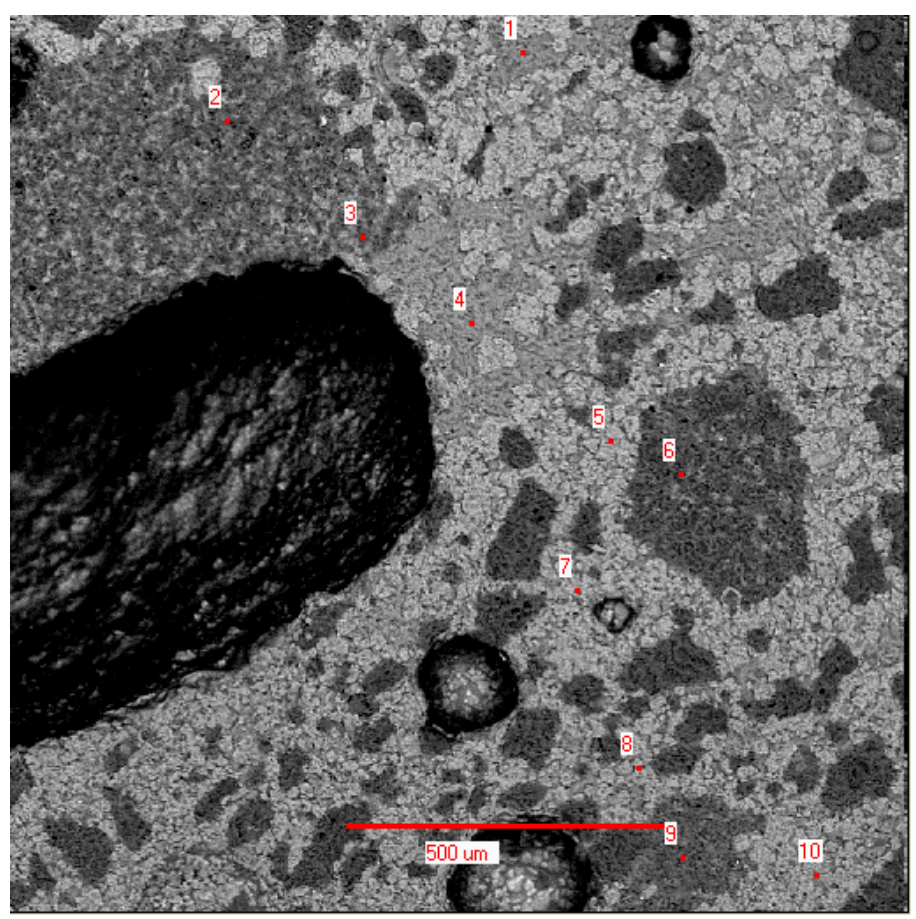

C

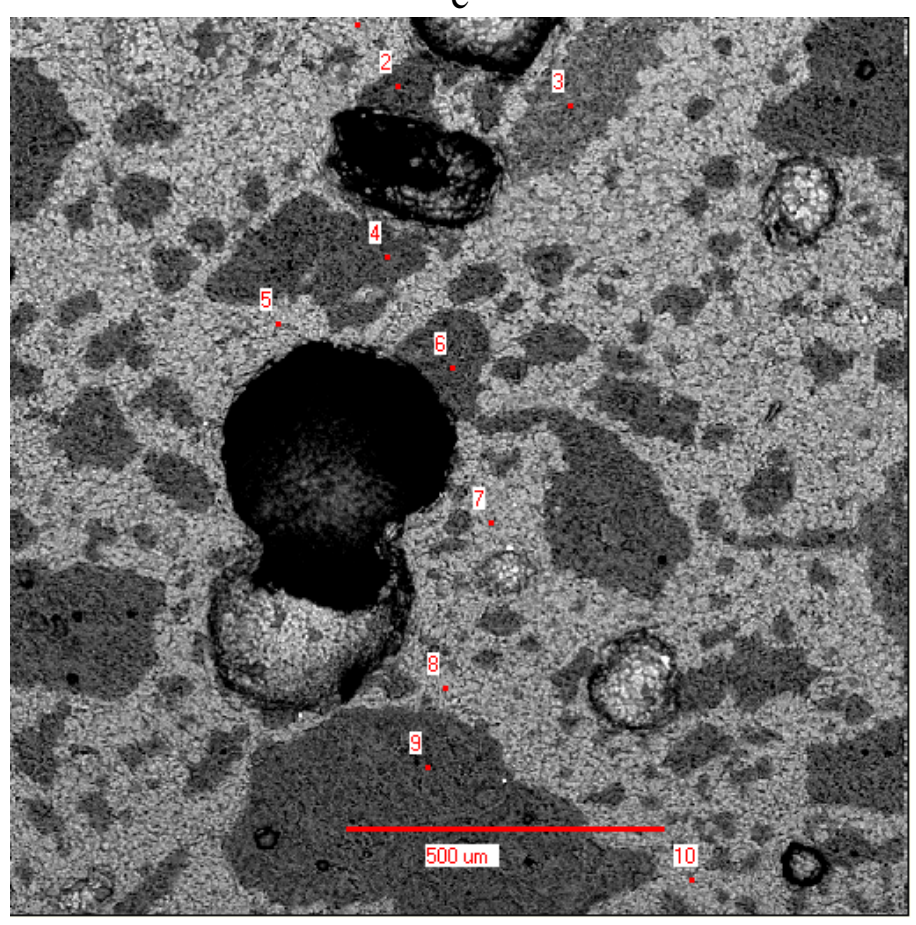

d

Figure 14 (cont.) . SEM Micrographs of the Cross Section of the BPMG Brick Tested by Slag B: (a) 1 to $2.5 \mathrm{~mm}$ below the Interface; (b) 2.5 to $4 \mathrm{~mm}$ below Interface; (c) 4 to $5.5 \mathrm{~mm}$ below the Interface; and (d) 5.5 to $7 \mathrm{~mm}$ below Interface (See Tables 9, 10, 11 and 12 for the analysis of the Points). 
Table 9. SEM Elemental Analysis of Brick BPMG Corroded by Slag B, wt\% (1 to $2.5 \mathrm{~mm}$ below the interface). Refer to figure 14a.

\begin{tabular}{cccccccccccccc}
\hline Point & Phase & $\mathrm{Na}$ & $\mathrm{Mg}$ & $\mathrm{Al}$ & $\mathrm{Si}$ & $\mathrm{S}$ & $\mathrm{K}$ & $\mathrm{Ca}$ & $\mathrm{Ti}$ & $\mathrm{Cr}$ & $\mathrm{Fe}$ & $\mathrm{Ni}$ & $\mathrm{V}$ \\
\hline 1 & Spinel & 0.2 & 2.1 & 27.8 & 0.6 & 0.3 & 0.0 & 0.0 & 0.0 & 1.5 & 67.5 & 0.0 & 0.0 \\
2 & Al-Si & 0.6 & 0.3 & 14.0 & 47.7 & 0.0 & 6.4 & 10.1 & 0.0 & 0.0 & 20.8 & 0.0 & 0.0 \\
3 & Grain & 0.0 & 0.0 & 100 & 0.0 & 0.0 & 0.0 & 0.0 & 0.0 & 0.0 & 0.0 & 0.0 & 0.0 \\
4 & Al-Si & 0.3 & 0.4 & 11.7 & 41.0 & 0.0 & 5.1 & 10.0 & 2.2 & 0.0 & 29.1 & 0.0 & 0.0 \\
5 & Al-Si & 0.0 & 0.4 & 13.6 & 43.0 & 0.0 & 6.1 & 11.6 & 2.0 & 0.0 & 23.3 & 0.0 & 0.0 \\
6 & Grain & 0.0 & 0.0 & 99.0 & 1.0 & 0.0 & 0.0 & 0.0 & 0.0 & 0.0 & 0.0 & 0.0 & 0.0 \\
7 & Al-Si & 0.3 & 0.4 & 15.7 & 38.4 & 0.0 & 4.5 & 10.2 & 2.2 & 0.0 & 28.2 & 0.0 & 0.0 \\
8 & Grain & 0.0 & 0.0 & 100 & 0.0 & 0.0 & 0.0 & 0.0 & 0.0 & 0.0 & 0.0 & 0.0 & 0.0 \\
9 & Spinel & 0.0 & 3.5 & 31.1 & 0.0 & 0.0 & 0.0 & 0.0 & 0.0 & 0.0 & 65.4 & 0.0 & 0.0 \\
10 & Al-Si & 0.4 & 0.4 & 13.1 & 42.8 & 1.0 & 6.2 & 10.5 & 2.8 & 0.0 & 22.8 & 0.0 & 0.0 \\
11 & Al-Si & 0.4 & 0.4 & 12.7 & 39.0 & 0.0 & 5.2 & 11.8 & 2.7 & 0.0 & 27.8 & 0.0 & 0.0 \\
12 & Grain & 0.0 & 0.0 & 99.1 & 0.0 & 0.0 & 0.0 & 0.0 & 0.0 & 0.0 & 0.0 & 0.0 & 0.0 \\
\hline
\end{tabular}

Table 10. SEM Elemental Analysis of Brick BPMG Corroded by Slag B, wt\% (2.5 to $4 \mathrm{~mm}$ below the interface). Refer to figure $14 \mathrm{~b}$.

\begin{tabular}{|c|c|c|c|c|c|c|c|c|c|c|c|c|c|}
\hline int & Phase & $\mathrm{Na}$ & $\mathrm{Mg}$ & $\mathrm{Al}$ & Si & S & K & $\mathrm{Ca}$ & $\mathrm{Ti}$ & $\mathrm{Cr}$ & $\mathrm{Fe}$ & $\mathrm{Ni}$ & V \\
\hline 1 & Gra & 0.0 & 0.5 & 98.0 & 1.5 & 0.0 & 0.0 & 0.0 & 0.0 & 0.0 & 0.0 & 0.0 & $0 .($ \\
\hline 2 & $\mathrm{~S}$ & 0.0 & 2.9 & 29.2 & 2.7 & 0.0 & 0.0 & 0.0 & 0.0 & 0.0 & 65.2 & 0.0 & 9. \\
\hline 3 & A & 0.3 & 0.3 & 13.4 & 35.4 & 0.0 & 4.6 & 11.1 & 2.4 & 0.0 & 32.6 & 0.0 & 0.1 \\
\hline 4 & Grain & 0.0 & 0.0 & 100 & 0.0 & 0.0 & 0.0 & 0.0 & 0.0 & 0.0 & 0.0 & 0.0 & 0.1 \\
\hline 5 & Spin & 0.0 & 4.3 & 35.3 & 0.5 & 0.0 & 0.0 & 0.0 & 0.0 & 0.0 & 59.9 & 0.0 & 0.1 \\
\hline 6 & Al- & 0.3 & 0.0 & 12.0 & 41.4 & 0.8 & 5.7 & 10.9 & 2.3 & 0.0 & 26.7 & 0 & 0. \\
\hline 7 & Gl & 0.0 & 0.0 & 100 & 0.0 & 0.0 & 0.0 & 0.0 & 0.0 & 0.0 & 0.0 & 0.0 & 0. \\
\hline$\varepsilon$ & G & 0.0 & 0.0 & 100 & 0.0 & 0.0 & 0.0 & 0.0 & 0.0 & 0.0 & 0.0 & 0.0 & 0. \\
\hline 9 & Spinel & 0.0 & 3.2 & 32.8 & 0.7 & 0.0 & 0.0 & 0.0 & 0.0 & 0.0 & 63.2 & 0.0 & 0. \\
\hline
\end{tabular}

Additionally, some of the alumina grains were found in small particles (Figure 14, c, Points 3 and 6; Figure 14, d, Point 3), and Si, K, and Na were detected in them. These grains might have higher porosity than the others. Through the pores, aluminosilicate penetrated into the grains. 
Table 11. SEM Elemental Analysis of Brick BPMG Corroded by Slag B, wt\% (4 to $5.5 \mathrm{~mm}$ below the interface). Refer to figure 14c.

\begin{tabular}{cccccccccccccc}
\hline Point & Phase & $\mathrm{Na}$ & $\mathrm{Mg}$ & $\mathrm{Al}$ & $\mathrm{Si}$ & $\mathrm{S}$ & $\mathrm{K}$ & $\mathrm{Ca}$ & $\mathrm{Ti}$ & $\mathrm{Cr}$ & $\mathrm{Fe}$ & $\mathrm{Ni}$ & $\mathrm{V}$ \\
\hline 1 & Al-Si & 0.3 & 0.4 & 13.4 & 42.3 & 0.0 & 6.6 & 11.2 & 1.9 & 0.0 & 23.9 & 0.0 & 0.0 \\
2 & Grain 0.0 & 0.0 & 98.9 & 1.1 & 0.0 & 0.0 & 0.0 & 0.0 & 0.0 & 0.0 & 0.0 & 0.0 \\
3 & Grain* 0.0 & 0.0 & 74.3 & 11.7 & 1.3 & 1.2 & 4.6 & 0.0 & 0.0 & 6.8 & 0.0 & 0.0 \\
4 & Al-Si & 0.6 & 0.6 & 13.7 & 40.7 & 0.0 & 6.0 & 9.1 & 2.1 & 0.0 & 27.3 & 0.0 & 0.0 \\
5 & Spinel 0.0 & 4.2 & 30.6 & 5.4 & 0.0 & 0.8 & 0.0 & 0.0 & 0.0 & 59.1 & 0.0 & 0.0 \\
6 & Grain* 0.0 & 0.0 & 72.8 & 10.5 & 1.2 & 2.2 & 4.1 & 0.0 & 0.0 & 9.3 & 0.0 & 0.0 \\
7 & Al-Si & 0.0 & 4.8 & 33.5 & 4.3 & 0.0 & 0.8 & 0.0 & 0.0 & 0.0 & 56.7 & 0.0 & 0.0 \\
8 & Spinel 0.0 & 6.0 & 34.6 & 0.5 & 0.0 & 0.0 & 0.0 & 0.0 & 0.0 & 59.0 & 0.0 & 0.0 \\
9 & Al-Si & 0.5 & 0.8 & 28.4 & 33.6 & 0.0 & 4.3 & 10.5 & 1.9 & 0.0 & 20.1 & 0.0 & 0.0 \\
10 & Spinel 0.0 & 5.9 & 36.4 & 0.0 & 0.0 & 0.0 & 0.0 & 0.0 & 0.0 & 57.7 & 0.0 & 0.0 \\
\hline
\end{tabular}

* Grain particles.

Table 12. SEM Elemental Analysis of Brick BPMG Corroded by Slag B, wt\% (5.5 to $7 \mathrm{~mm}$ below the interface). Refer to figure $14 \mathrm{~d}$.

\begin{tabular}{cccccccccccccc}
\hline Point & Phase & $\mathrm{Na}$ & $\mathrm{Mg}$ & $\mathrm{Al}$ & $\mathrm{Si}$ & $\mathrm{S}$ & $\mathrm{K}$ & $\mathrm{Ca}$ & $\mathrm{Ti}$ & $\mathrm{Cr}$ & $\mathrm{Fe}$ & $\mathrm{Ni}$ & $\mathrm{V}$ \\
\hline 1 & Al-Si & 0.3 & 1.9 & 20.1 & 36.4 & 0.0 & 7.3 & 5.5 & 1.8 & 0.0 & 26.7 & 0.0 & 0.0 \\
2 & Grain 0.0 & 0.5 & 99.5 & 0.0 & 0.0 & 0.0 & 0.0 & 0.0 & 0.0 & 0.0 & 0.0 & 0.0 \\
3 & Grain* 0.5 & 0.5 & 68.5 & 19.7 & 0.0 & 0.0 & 3.5 & 0.0 & 0.0 & 7.4 & 0.0 & 0.0 \\
4 & Grain 0.0 & 0.0 & 100 & 0.0 & 0.0 & 0.0 & 0.0 & 0.0 & 0.0 & 0.0 & 0.0 & 0.0 \\
5 & Spinel 0.0 & 6.9 & 36.9 & 1.2 & 0.5 & 0.0 & 0.0 & 0.0 & 0.0 & 54.6 & 0.0 & 0.0 \\
6 & Grain 0.0 & 0.5 & 99.5 & 0.0 & 0.0 & 0.0 & 0.0 & 0.0 & 0.0 & 0.0 & 0.0 & 0.0 \\
7 & Al-Si 0.0 & 1.4 & 18.6 & 38.4 & 0.0 & 10.3 & 7.5 & 2.5 & 0.0 & 21.3 & 0.0 & 0.0 \\
8 & Spinel 0.0 & 9.4 & 43.9 & 0.7 & 0.0 & 0.0 & 0.0 & 0.0 & 0.0 & 46.1 & 0.0 & 0.0 \\
9 & Grain 0.0 & 0.3 & 99.5 & 0.0 & 0.0 & 0.0 & 0.0 & 0.0 & 0.0 & 0.0 & 0.0 & 0.0 \\
10 & Spinel 0.0 & 8.9 & 39.4 & 0.8 & 0.0 & 0.0 & 0.0 & 0.0 & 0.0 & 50.8 & 0.0 & 0.0 \\
\hline
\end{tabular}

* Grain particles.

Below the slag-refractory interface of Sample A, no iron penetration was measured or observed in the refractory matrix, however, significant iron penetration is found in Sample B (refer to Tables 7 and 8 for Slag A). A probable reason for this might be that Slag A has a lower iron oxide content; the iron oxide has been consumed before entering the brick, either reduced to iron metal by hydrogen or forming some high melting compounds left on the brick surface. Slag B has much more iron oxide than Slag A; therefore, some iron could survive the hydrogen reduction and infuse into the refractory. 
In order to investigate the penetration behavior of individual elements, the matrix composition change with depth into the refractory has been studied, and the data are shown in Tables 13 and 14 .

Table 13. Matrix Composition Changes in the Slag A Tested BPMG Brick, wt\%.

\begin{tabular}{crcccccc}
\hline Depth, & \multicolumn{7}{c}{ Elemental Concentrations } \\
\cline { 2 - 8 } $\mathrm{mm}$ & $\mathrm{Si}$ & $\mathrm{Al}$ & $\mathrm{Fe}$ & $\mathrm{Ca}$ & $\mathrm{Mg}$ & $\mathrm{Na}$ & $\mathrm{K}$ \\
\hline 0.0 & 43.4 & 19.3 & 0.0 & 15.9 & 2.1 & 1.1 & 5.6 \\
0.5 & 44.0 & 20.1 & 0.0 & 15.1 & 2.2 & 1.1 & 6.1 \\
1.5 & 42.7 & 19.0 & 0.0 & 16.6 & 2.1 & 1.1 & 5.1 \\
3.0 & 43.2 & 19.2 & 0.0 & 15.9 & 2.1 & 1.3 & 5.7 \\
5.0 & 42.7 & 19.2 & 0.0 & 15.0 & 2.0 & 1.1 & 6.4 \\
7.0 & 44.6 & 18.9 & 0.0 & 16.7 & 1.8 & 1.2 & 4.9 \\
10.0 & 4.6 & 63.7 & 0.0 & 2.6 & 12.1 & 0.0 & 0.0 \\
\hline
\end{tabular}

Table 14. Matrix Composition Changes in the Slag B Tested BPMG Brick, wt\%.

\begin{tabular}{|c|c|c|c|c|c|c|c|}
\hline \multirow{2}{*}{$\begin{array}{l}\text { Depth, } \\
\text { mm }\end{array}$} & \multicolumn{7}{|c|}{ Elemental Concentrations } \\
\hline & $\mathrm{Si}$ & $\mathrm{Al}$ & $\mathrm{Fe}$ & $\mathrm{Ca}$ & $\mathrm{Mg}$ & $\mathrm{Na}$ & $\mathrm{K}$ \\
\hline 0.0 & 7.2 & 22.9 & 59.7 & 1.2 & 1.5 & 0.2 & 1.5 \\
\hline 1.5 & 17.4 & 23.2 & 46.6 & 2.6 & 1.7 & 0.0 & 2.7 \\
\hline 3.0 & 21.4 & 20.3 & 41.7 & 3.6 & 2.2 & 0.3 & 3.4 \\
\hline 5.0 & 14.2 & 32.2 & 39.2 & 1.8 & 3.4 & 0.0 & 2.3 \\
\hline 7.5 & 19.9 & 37.3 & 20.3 & 3.0 & 6.2 & 0.3 & 3.2 \\
\hline 10.0 & 17.2 & 48.9 & 7.4 & 3.7 & 5.6 & 0.0 & 4.5 \\
\hline 13.0 & 3.3 & 61.5 & 0.0 & 3.5 & 13.0 & 0.5 & 2.9 \\
\hline
\end{tabular}

Significant penetration of silicon and calcium were measured in the Slag A tested brick, and small quantities of potassium and sodium also infused into the matrix. At the same time, the aluminum and magnesium concentrations are much higher in the deep matrix within the refractory than in the matrix just below the interface. As to the Slag B tested refractory, the change in composition of silicon, calcium, potassium, sodium, aluminum, and magnesium was similar to trends found in Slag A tested brick. In addition to those elements, a mass of iron penetrated into the refractory matrix. The results imply that slags were reacting with the matrix 
and dissolving the bonds between the grains, resulting in a gradual corrosive loss of refractory.

As slag infused through the refractory, the penetration depth differed from element to element. The relative depth of slag penetration into the BPMG refractory is shown in Figure 15. Within the Slag A tested brick, silicon and calcium penetrated the deepest $(>10 \mathrm{~mm})$ into the matrix, followed by potassium and sodium $(<10 \mathrm{~mm})$. A similar phenomenon was found in the Slag B tested sample (>13 $\mathrm{mm}$ for silicon and calcium), except potassium also penetrated to a depth greater than $13 \mathrm{~mm}$. In addition, the iron penetration in this sample is more significant than silicon but limited to a depth of less than $13 \mathrm{~mm}$. The results are in agreement with a previous study on slag penetration into a high-chrome oxide-alumina refractory [11].

Figure 15-a shows that the refractory components ( $\mathrm{Al}$ and $\mathrm{Mg}$ ) begin to dominate the refractory matrix at a depth of around $8 \mathrm{~mm}$ below the slag-refractory interface. This is very close to the boundary of the black layer. In Figure 15-b, the refractory components exceed the slag components at a depth of around $5.5 \mathrm{~mm}$, and it is also close to the boundary between the black layer and white layer. The results strongly suggest that within the slag-penetrated area, the black layer is a phase rich in slag elements and with low refractory content. Once refractory content dominates the matrix, it appears white in color.

In the Slag B tested brick, slag reacted with refractory matrix and formed two different phases (a mixture of aluminosilicate and spinel and separated aluminosilicate and spinel), and refractory content begins to dominate in the mixture phase, so there is clearly a white layer (mixture phase with a high aluminum concentration) behind the black layer (separated phase with a low aluminum concentration). As to the Slag A tested brick, slag and refractory matrix formed only one phase (aluminosilicate), so the white layer is not visible (refer to Figure 10). 


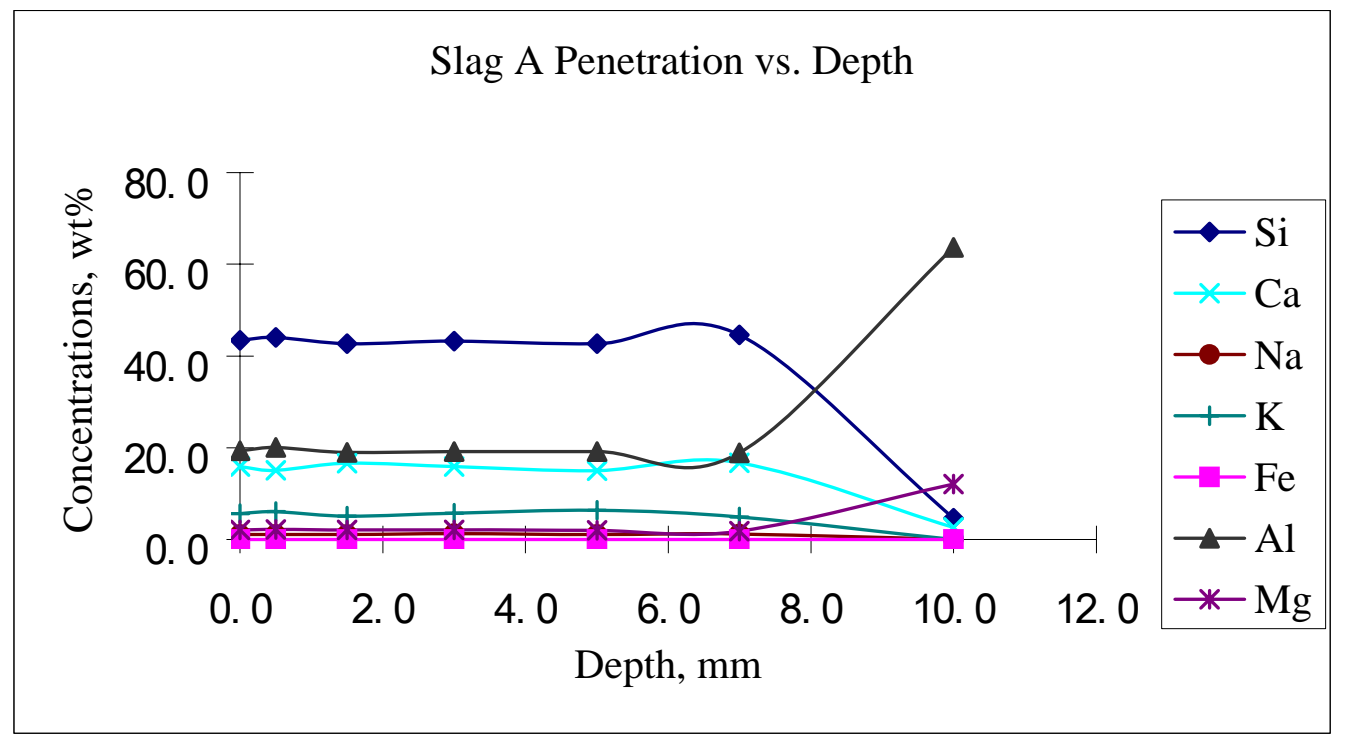

a

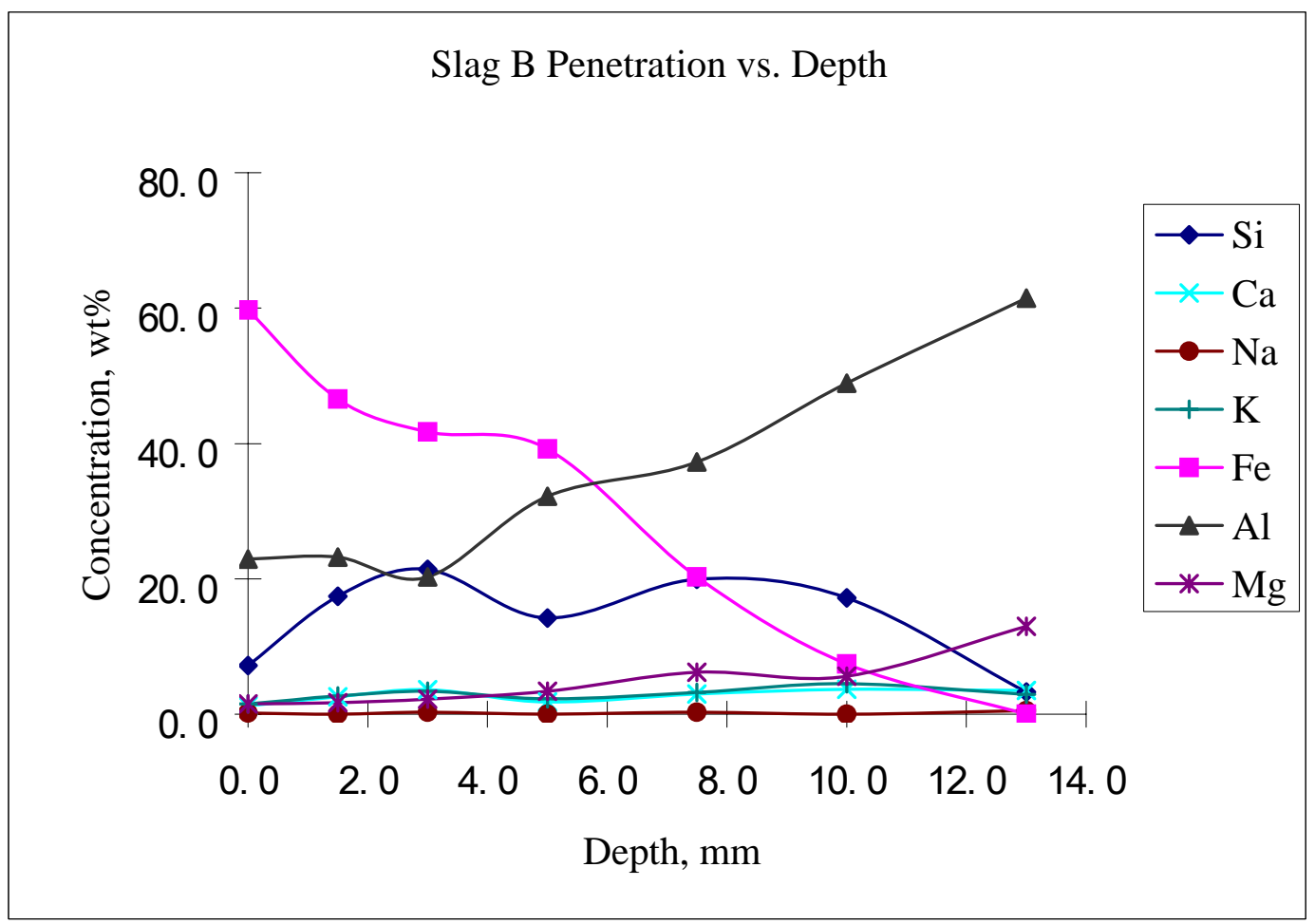

b

Figure 15. Elemental Penetration below the Interface of Brick BPMG: (a) Slag A Penetration and (b) Slag B Penetration. 


\subsection{WDXRF Analysis}

All of the spent slags were collected and examined using WDXRF. Table 16 provides the WDXRF data for Slag A and shows the iron concentration decreased by $24 \%$ after testing with brick BPMG. However, no iron penetration into the refractory was found in the SEM analysis. At initial glance, the WDXRF results seem to be misleading, even after considering that there might be some iron left on the brick surface. The apparent dilution of iron is actually due to the large quantity of aluminum dissolved from the refractory by the slag, diluting the slag with aluminum. Further analysis of Slag A to a non-aluminum basis is shown in Table 16. Besides the “decrease” in iron concentration, the silicon concentration was found to increase by 5.8\%, and this also conflicts with the SEM result showing that silicon penetrated to the refractory in the test. One possible reason for this is that most of the slag components exchanged with the refractory, and all of these exchanges contributed to the modification of the "slag basis." However, it is more likely that due to the heterogeneous nature of the slag and the small sample used for the WDXRF analysis that the results carry a large combined analytical and experimental error. Therefore, only the significant concentration change (greater than $30 \%$ for Slag A and greater than 15\% for Slag B [the values were developed based on the SEM results]) was used to approximate any elemental exchange that may have happened in the tests. The significant data is listed in Tables 17 and 18.

The selected data indicate that both slags dissolved aluminum from the high-aluminum bricks and dissolved chromium from the high-chrome ones. Slag B dissolved magnesium from all of the bricks it corroded. In addition, Slag B also dissolved sodium from the high-aluminum refractory but released sodium to the high-chrome refractory. After data filtration, the WDXRF analysis gives very limited information for understanding the slag-refractory interaction. 
Table 15. WDXRF Analysis Report of Slag A, wt.\%.

\begin{tabular}{cccccccc}
\hline \multirow{2}{*}{ Slag A } & \multicolumn{7}{c}{ After CADCAF test } \\
\cline { 2 - 8 } & Initial & I & Difference & BPMG & Difference & Tampa & Difference \\
\hline $\mathrm{Si}$ & 42.4 & 37.5 & $-12 \%$ & 40.5 & $-5 \%$ & 41.8 & $-1 \%$ \\
$\mathrm{Al}$ & 16.7 & 24.7 & $48 \%$ & 24.8 & $49 \%$ & 17.0 & $2 \%$ \\
$\mathrm{Fe}$ & 15.5 & 13.5 & $-13 \%$ & 11.8 & $-24 \%$ & 15.7 & $1 \%$ \\
$\mathrm{Ti}$ & 1.0 & 0.9 & $-10 \%$ & 0.9 & $-10 \%$ & 1.1 & $10 \%$ \\
$\mathrm{P}$ & 0.2 & 0.2 & $0 \%$ & 0.1 & $-50 \%$ & 0.3 & $50 \%$ \\
$\mathrm{Ca}$ & 6.7 & 7.6 & $13 \%$ & 6.4 & $-5 \%$ & 6.6 & $-2 \%$ \\
$\mathrm{Mg}$ & 1.7 & 1.9 & $12 \%$ & 2.3 & $35 \%$ & 1.8 & $6 \%$ \\
$\mathrm{Na}$ & 6.9 & 6.2 & $-10 \%$ & 6.9 & $0 \%$ & 6.2 & $-10 \%$ \\
$\mathrm{~K}$ & 3.1 & 2.6 & $-16 \%$ & 2.9 & $-7 \%$ & 3.0 & $-3 \%$ \\
$\mathrm{Ni}$ & 0.7 & 0.8 & $14 \%$ & 0.3 & $-57 \%$ & 0.7 & $0 \%$ \\
$\mathrm{~V}$ & 4.4 & 4.1 & $-7 \%$ & 2.9 & -34. & 5.8 & $32 \%$ \\
$\mathrm{Cr}$ & 0.08 & 0.07 & $-13 \%$ & 0.06 & $-25 \%$ & 0.61 & $662 \%$ \\
\hline
\end{tabular}

Table 16. WDXRF Analysis of Slag A to a Non-Aluminum Basis, wt\%.

\begin{tabular}{cccc}
\hline $\begin{array}{c}\text { Slag } \\
\mathrm{A}\end{array}$ & Initial & $\begin{array}{c}\text { After testing } \\
\text { with BPMG }\end{array}$ & Difference \\
\hline $\mathrm{Si}$ & 50.9 & 53.9 & $6 \%$ \\
$\mathrm{Fe}$ & 18.6 & 15.7 & $-16 \%$ \\
$\mathrm{Ca}$ & 8.0 & 8.5 & $6 \%$ \\
$\mathrm{Mg}$ & 2.0 & 3.1 & $50 \%$ \\
$\mathrm{Na}$ & 8.3 & 9.2 & $11 \%$ \\
$\mathrm{~K}$ & 3.7 & 3.9 & $4 \%$ \\
$\mathrm{~V}$ & 5.3 & 3.9 & $-27 \%$ \\
\hline
\end{tabular}

Table 17. Elemental Changes in the CADCAF Tests with Slag A, wt\%.

\begin{tabular}{cccccccc}
\hline \multirow{2}{*}{ Slag A A } & \multicolumn{7}{c}{ After the CADCAF test } \\
\cline { 2 - 8 } & Initial & I & Difference & BPMG & Difference & Tampa & Difference \\
\hline $\mathrm{Al}$ & 16.7 & 24.7 & $48 \%$ & 24.8 & $49 \%$ & - & - \\
$\mathrm{P}$ & 0.2 & - & - & 0.1 & $-50 \%$ & 0.3 & $50 \%$ \\
$\mathrm{Mg}$ & 1.7 & - & - & 2.3 & $35 \%$ & - & - \\
$\mathrm{Ni}$ & 0.7 & - & - & 0.3 & $-57 \%$ & - & - \\
$\mathrm{V}$ & 4.4 & - & - & 2.9 & $-34 \%$ & 5.8 & $32 \%$ \\
$\mathrm{Cr}$ & 0.08 & - & - & - & - & 0.61 & $662 \%$ \\
Differences less than 30\% are noted by a “_“ & & \\
\hline
\end{tabular}


Table 18. Elemental Changes in the CADCAF Tests with Slag B, wt\%.

\begin{tabular}{cccccccc}
\hline \multirow{2}{*}{ Slag B B After the CADCAF test } \\
\cline { 2 - 8 } & Initial & I & Difference & BPMG & Difference & A90 & Difference \\
\hline $\mathrm{Al}$ & 16.6 & 22.9 & $38 \%$ & 19.4 & $17 \%$ & - & - \\
$\mathrm{Ca}$ & 2.8 & - & - & - & - & 3.5 & $25 \%$ \\
$\mathrm{Mg}$ & 0.9 & 1.2 & $33 \%$ & 1.1 & $22 \%$ & 1.3 & $44 \%$ \\
$\mathrm{Na}$ & 0.9 & 1.1 & $22 \%$ & - & - & 0.7 & $-22 \%$ \\
$\mathrm{~K}$ & 3.0 & - & - & - & - & 3.8 & $28 \%$ \\
$\mathrm{Cr}$ & 0.0 & - & - & - & - & 0.31 & - \\
Differences less than & 15\% are noted by a “_“ & & \\
\hline
\end{tabular}

\subsection{Slag Corrosion Mechanism}

Based on the results and analysis, the corrosion mechanism hypothesis of BPMG refractory exposed to Slag A is proposed by using the following processes:

(1) Slag melting

Slag (solid) $\rightarrow$ Slag (liquid)

(2) Iron oxide converts to high melting solid

Possible reaction:

$\mathrm{FeO}+\mathrm{H}_{2} \rightarrow \mathrm{Fe}_{\text {(solid) }}+\mathrm{H}_{2} \mathrm{O}$

(3) Slag elements penetrate to the refractory as oxides ( $\mathrm{Si}, \mathrm{Ca}, \mathrm{Ni}, \mathrm{K}, \mathrm{Na}$ )

(4) Slag-refractory reaction producing aluminosilicate-based phase

Main reaction:

$\mathrm{MO}_{\mathrm{x}}+\mathrm{Al}_{2} \mathrm{O}_{3}+\mathrm{SiO}_{2} \rightarrow \mathrm{M}_{\mathrm{x}} \mathrm{AlSi}_{2.2} \mathrm{O}_{\mathrm{y}}(\mathrm{M}=\mathrm{Ca}, \mathrm{K}$ and $\mathrm{Na})$

(5) Refractory particles debonding: dissolving of refractory bonds and particles infusing into slag 
(6) Slag-refractory physical mismatch: variation in properties causing refractory disruption and fragmentation

(7) Slag wear-abrasion-erosion

For the BPMG refractory exposed to Slag B a potential mechanism may be:

(1) Slag melting

Slag (solid) $\rightarrow$ Slag (iquid)

(2) Iron oxide converts to high melting solid

Possible reaction:

$\mathrm{FeO}+\mathrm{H}_{2} \rightarrow \mathrm{Fe}$ (solid) $+\mathrm{H}_{2} \mathrm{O}$

(3) Slag elements penetrate to the refractory as oxides ( $\mathrm{Si}, \mathrm{Fe}, \mathrm{Ca}, \mathrm{K}, \mathrm{Na}$ )

(4) Slag-refractory reaction producing a mixture of two new phases:

-Phase A, aluminosilicate-based

$\mathrm{MO}_{\mathrm{x}}+\mathrm{Al}_{2} \mathrm{O}_{3}+\mathrm{SiO}_{2} \rightarrow \mathrm{M}_{\mathrm{x}} \mathrm{AlSi}_{2} \mathrm{O}_{\mathrm{y}} ;(\mathrm{M}=\mathrm{Fe}, \mathrm{Ca}, \mathrm{K}, \mathrm{Na}, \mathrm{Ti}$ and $\mathrm{Mg})$

- Phase B, spinel-based

$\mathrm{FeO}+\mathrm{Al}_{2} \mathrm{O}_{3} \rightarrow(\mathrm{Fe}, \mathrm{Al})_{3} \mathrm{O}_{4}$

$\mathrm{MgO}+\mathrm{Al}_{2} \mathrm{O}_{3} \rightarrow(\mathrm{Mg}, \mathrm{Al})_{3} \mathrm{O}_{4}$

$\mathrm{FeO}+\mathrm{Al}_{2} \mathrm{O}_{3} \rightarrow\left(\mathrm{Fe}, \mathrm{Al}_{3} \mathrm{O}_{4}\right.$

$\mathrm{MgO}+\mathrm{Cr}_{2} \mathrm{O}_{3} \rightarrow\left(\mathrm{Cr}, \mathrm{Al}_{3} \mathrm{O}_{4}\right.$

(5) The two solid phases crystallize and separate from each other

(6) Refractory particles debonding: dissolving of refractory bonds and particles infusing into slag

(7) Slag-refractory physical mismatch: variation in properties causing refractory disruption and fragmentation 
(8) Slag wear-abrasion-erosion

\section{CONCLUSIONS AND RECOMMENDATIONS}

The CADCAF tests of commercial refractories have been performed and show that 1) the color of the slag-penetrated area is dependent on the slag and refractory contents; with high slag content, the color appears in black; with high refractory content, it appears in white; 2) highchrome refractories have greater corrosion resistance than high-aluminum refracotries based upon the CADCAF tests; 3) coal slag readily diffuses into the refractory through its grain boundaries; 4) the refractory grains are more stable than the matrix in the tests, and the grains are the first line of defense against corrosion; 5) calcium and alkali in the slag are more corrosive than iron; and 6) silicon and calcium penetrate the deepest into the refractory. The results obtained from this study are preliminary and should be combined with result from other research programs. In particular, the refractory corrosion results from this study should be compared with refractories removed from commercial gasifiers. 


\section{REFERENCES}

1. National Energy Technology Center, "A Current Perspective on the Gasification Industry, World Survey Results 2004”, www.doe.netl.gov.

2. Greenberg, S., \& Poeppel, R.B. The corrosion of ceramic refractories exposed to a synthetic coal slag by means of the rotating-drum technique. Research Report ANL/FE-85-9, research sponsored by U.S. DOE/FE, 15.

3. Greenberg, S., \& Poeppel, R.B. (1986). The corrosion of ceramic refractories exposed to synthetic coal slags by means of the rotating-drum technique: Final Report. Research Report ANL/FE-85-9, research sponsored by U.S. DOE/FE and EPRI, 66.

4. Kennedy, C.R., \& Poeppel, R.R. (1978). The corrosion of refaractories exposed to molten acidic coal-ash slags. Interceram, 27 (3) 221-26.

5. Kennedy, C.R. (1978). Evaluation of ceramic refractories for slagging gasifiers: Summary of progress to date. Research sponsored by U.S. DOE, ANL report 56, 78-61.

6. Starzacher, A.P. (1988). Picrochromite Brich - a qualified material for Texaco slagging gasifiers. Radex Rundschau, 1, 491-501.

7. Rawers, J., Kwong, J., \& Bennett, J. (1999). Characterizing coal-gasifier slag-refractory interactions. Materials at High Temperatures, 16 (4), 219-222.

8. Guo, Z. (2004). Refractories for gasifiers. American Ceramic Society Bulletin, 83 (6) 91019108.

9. Bakker, W.T., Trondt, M., \& Gerhardus, U. (1984). Refractory practice in slagging gasifiers. American Ceramic Society Bulletin, 63 (7), 870-876.

10. Bakker, W.T. (1993). Refractories for present and future electric power plants. Key Engineering Materials Trans Tech Publications, 88, 41-70.

11. Bennett, J.P., \& Kwong, K. (2003). Refractory liner materials used in slagging gasifiers. Refractories Application and News, 9 (5), 20-25.

12. Rawers, J., Collins, K., \& Peck, M. (2001). Oxides reactions with a high-chrome sesquioxide refractory. Journal of Material Science, 36, 4837-4843.

13. Li, Z., Mukai, M., \& Tao, Z. (2000). Reactions between MgO-C refractory, molten slag, and metal. The Iron and Steel Institute of Japan International, Supplement, 40, 101-105. 
14. Kim, H.B., \& Oh, M. Corrosion of chromia refractory by coal slag under reducing conditions. Retrieved from the Web site: http://www.etis.net/balpyo/ clean5/08.pdf.

15. Yang, H.Y., \& Chan, C.F. (1990). Corrosion resistance and microstructure of high-alumina refractories based on the rotary slag test. Journal of the American Ceramic Society, 7, 10741077.

16. Yamaguchi, A. (1986). Sintering of compositions in the system $\mathrm{Al}_{2} \mathrm{O}_{3}-\mathrm{Cr}_{2} \mathrm{O}_{3}-\mathrm{SiO}_{2}$. Ceramics International, 12, 19-24,

17. Konsztowicz, K.J., \& Boutin, J. (1993). Study of porosity in corroded refractories. Journal of the American Ceramic Society, 76, 1169-1176.

18. Frohlich, L., Frohlichova, M., Janak, G., \& Lohay, T. (2000). Microstructure of highalumina refractory building materials and its influence on corrosion. Metallurgy, 39, 119123.

19. Kashcheev, I.D., \& Semyannikov, V.P. (1993). Role of structural factors in improving the corrosion resistance of refractories. Refractories, 34, 449-453.

20. Godard, H.T., Kotacska, L.H., \& Wosinski, J.F. (1997). Refractory corrosion behaviour under air-fuel and oxy-fuel environments. Ceramic Engineering and Science Proceedings, 18, 180-207.

21. Mukai, K. (1998). Marangoni flows and corrosion of refractory walls. Philosophical Transactions of The Royal Society of London A, 356, 1015-1026.

22. Triantafyllidis, D., Stott, F.H. \& Li, L. (2003). The slag corrosion behavior of laser surface treated refractory ceramics. Retrieved from the Journal of Corrosion Science and Engineering (JCSE) Web site: http://www.jcse.org/ Volume6/ Preprints/V6Preprint94.pdf.

23. Strobel, T.M., \& Hurley, J.P. (1995). Coal-ash corrosion of monolithic silicon carbide-based refracotries. Fuel Processing Technology, 44, 201-211.

24. Hurley, J.P., \& Patty, P.L. (2003). Very-high-temperature corrosion of chromia- and alumina-forming alloys in coal combustion systems. Retrieved from the National Energy Technology Laboratory Web site: http://www.netl.doe.gov/ publications/proceedings/ 03/materials/manuscripts/Hurley_m.pdf.

25. Hurley, J.P., Keleven, P.L., \& Sutton, W. (2001). Bench-scale measurements of refractory corrosion by flowing slag. Proceedings of the Engineering Foundation Conference: Effects of Coal Quality on Power Plant Management: Ash Problems, Management, and Solutions; EPRI 1001402, 3-60-3-75.

26. Shukla, D. (2005) Dynamic testing of gasifier refractory. M.S. Thesis, University of North Dakota. 
27. Hong, X. (2005) Characterization Of Refractory Corrosion By Flowing Slag. M.S. Thesis, University of North Dakota.

28. Taber, Wade A. (2003). Refractories for gasification. Refractories Application and News, 8 (4), 18-23.

29. Carniglia, S., \& Barna, G. Handbook of industrial refractory technologies. Noyes Publications, 241.

30. Browing, G.J., Bryant, G.W., Hurst, H.J., Lucas, J.A., \& Wall, T.F. (2003). An empirical method for the prediction of coal ash slag viscosity. Energy and Fuels, 17, 731-737.

31. Rezaie, A., Headrick, W., Fahrenholtz, W., Moore, R., Velez, M., \& Davis, A. (2004). Interaction of refractories and alkaline-containing corrodants. Refractories Application and News, 9 (5), 26-29.

32. Winegartner, E.C. (1974). Coal fouling and slagging parameters. ASME Research Committee on Corrosion and Deposits from Combustion Gases, ASME Publications. 